Prepared in cooperation with the City of Wichita, Kansas

\title{
Status of Groundwater Levels and Storage Volume in the Equus Beds Aquifer near Wichita, Kansas, 2012 to 2014
}

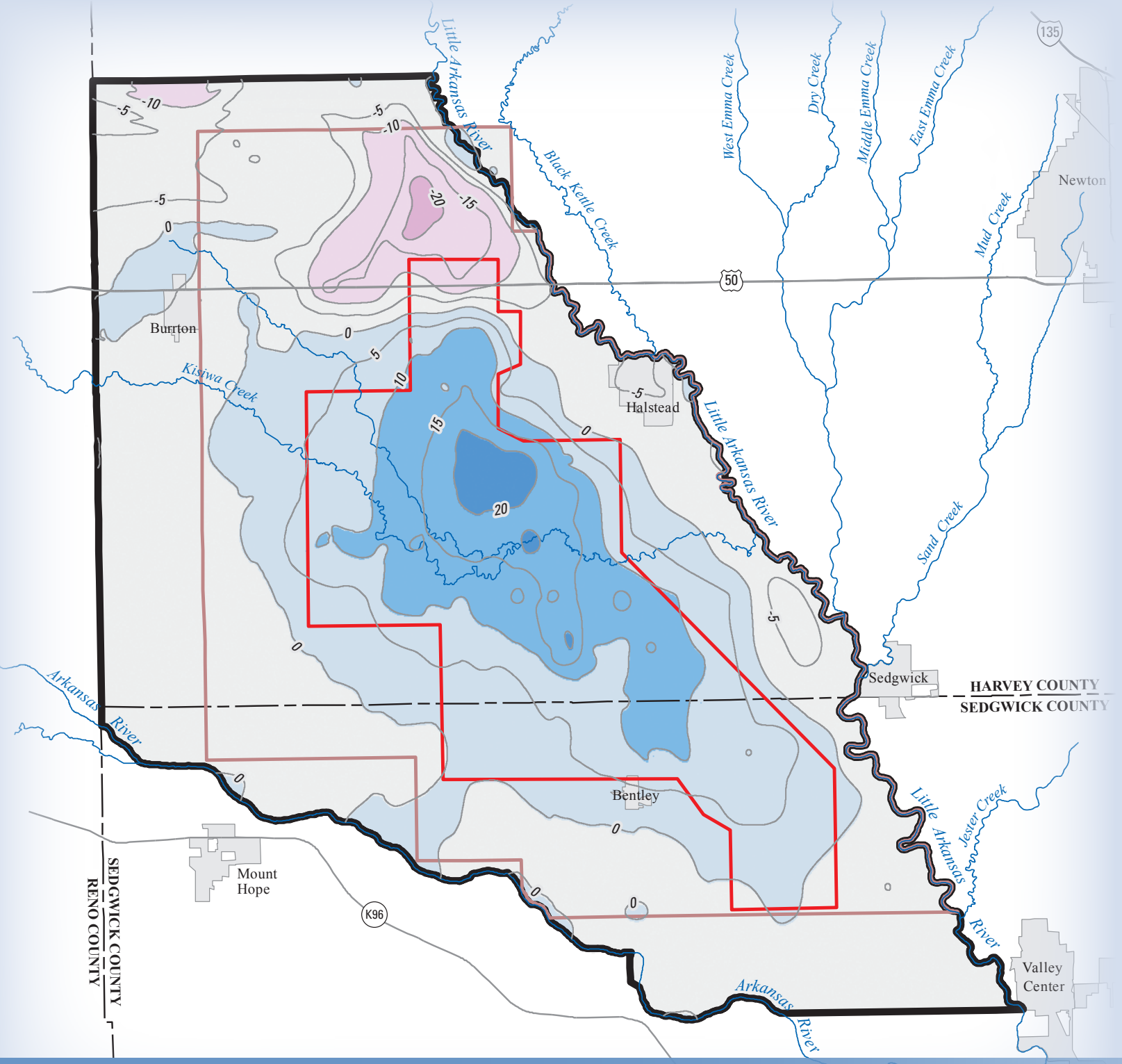

Scientific Investigations Report 2014-5185

U.S. Department of the Interior

U.S. Geological Survey 
Front cover. Figure 18 of this report. 


\section{Status of Groundwater Levels and Storage Volume in the Equus Beds Aquifer near Wichita, Kansas, 2012 to 2014}

By Cristi V. Hansen, Joshua A. Whisnant, and Jennifer L. Lanning-Rush

Prepared in cooperation with the City of Wichita, Kansas

Scientific Investigations Report 2014-5185 


\title{
U.S. Department of the Interior SALLY JEWELL, Secretary
}

\section{U.S. Geological Survey Suzette M. Kimball, Acting Director}

\author{
U.S. Geological Survey, Reston, Virginia: 2014
}

For more information on the USGS - the Federal source for science about the Earth, its natural and living resources, natural hazards, and the environment, visit http://www.usgs.gov or call 1-888-ASK-USGS.

For an overview of USGS information products, including maps, imagery, and publications, visit http://www.usgs.gov/pubprod

To order this and other USGS information products, visit http://store.usgs.gov

Any use of trade, firm, or product names is for descriptive purposes only and does not imply endorsement by the U.S. Government.

Although this information product, for the most part, is in the public domain, it also may contain copyrighted materials as noted in the text. Permission to reproduce copyrighted items must be secured from the copyright owner.

Suggested citation:

Hansen, C.V., Whisnant, J.A., and Lanning-Rush, J.L., 2014, Status of groundwater levels and storage volume in the Equus Beds aquifer near Wichita, Kansas, 2012 to 2014: U.S. Geological Survey Scientific Investigations Report 2014-5185, 39 p., http://dx.doi.org/10.3133/sir20145185.

ISSN 2328-0328 (online) 


\section{Acknowledgments}

The authors acknowledge the assistance of Michael Jacobs, Debra Ary, Rich Robinson, and staff of the city of Wichita; and Tim Boese, Steve Flaherty, and staff of Equus Beds Groundwater Management District Number 2 for providing water-level data and for their technical reviews, which contributed to improved technical and editorial clarity of the report.

Technical reviews by U.S. Geological Survey employees Brian Kelly and Geoff Delin also contributed to improved technical and editorial clarity of the report. 


\section{Contents}

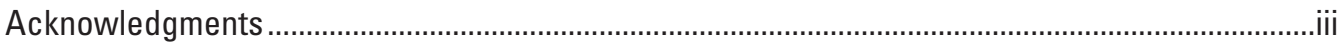

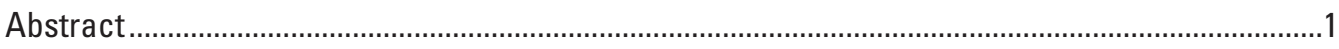

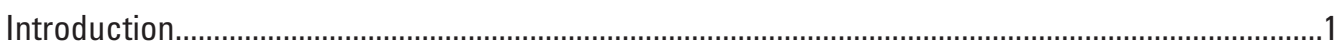

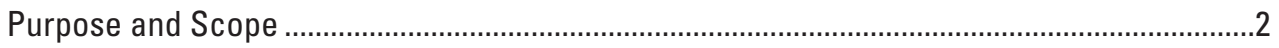

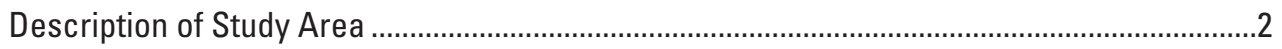

Hydrogeology of the Study Area ..........................................................................................

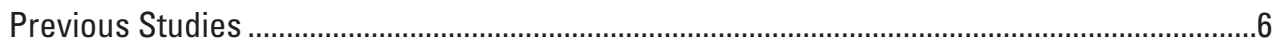

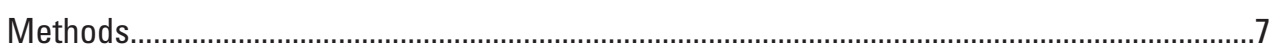

Shallow and Deep Parts of the Equus Beds Aquifer ........................................................

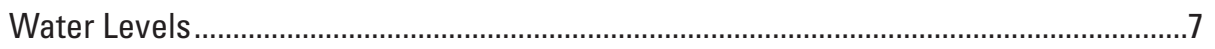

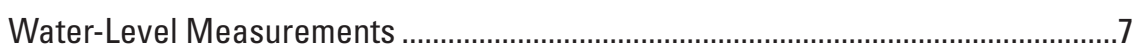

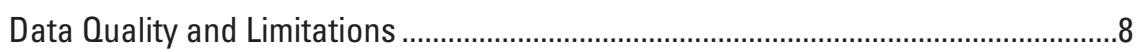

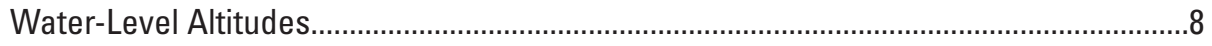

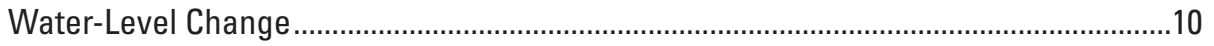

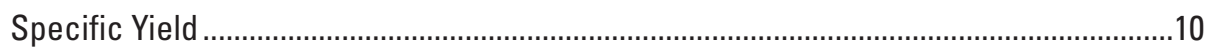

Total Aquifer Storage Volume ................................................................................10

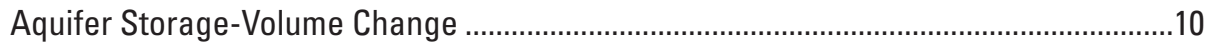

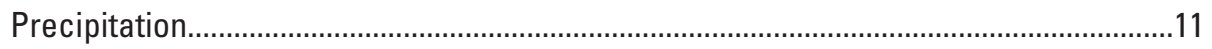

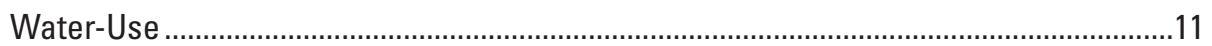

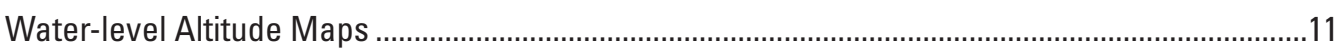

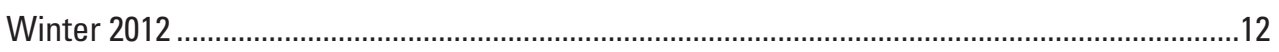

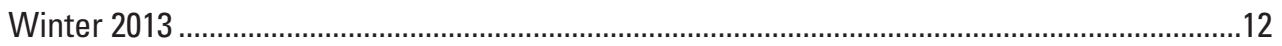

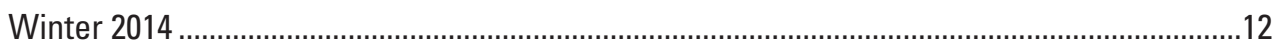

Summer 2012

Water-Level and Storage-Volume Changes in the Equus Beds Aquifer ........................................19

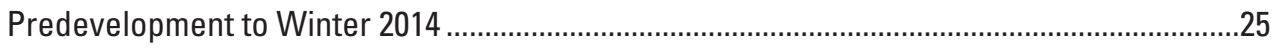

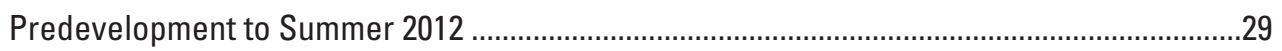

1993 to Winter 2014

1993 to Summer 2012

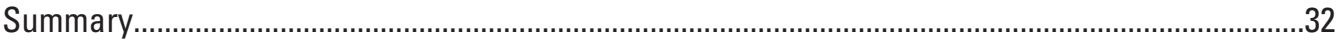

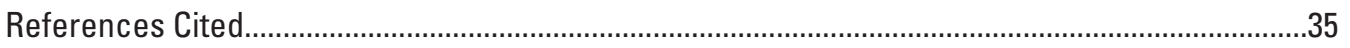

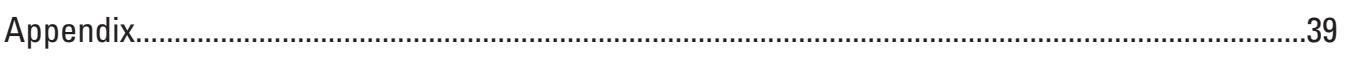

\section{Figures}

1. Map showing location of study area near Wichita, south-central Kansas........................3

2. Graphs showing relation of precipitation and water use for the city of Wichita public supply and agricultural irrigation in the study area, 1938 through $2013 \ldots \ldots \ldots \ldots \ldots . . . .5$

3. Graph showing statistical relation between annual groundwater irrigation use and average annual precipitation in the study area, 1988 through 2012. 
4. Map showing static water-level altitudes in the shallow part of the Equus Beds aquifer, winter 2012 .

5. Map showing static water-level altitudes in the deep part of the Equus Beds aquifer, winter 2012 .

6. Map showing static water-level altitudes in the shallow part of the Equus Beds aquifer, winter 2013 .

7. Map showing static water-level altitudes in the deep part of the Equus Beds aquifer, winter 2013 .

8. Map showing static water-level altitudes in the shallow part of the Equus Beds aquifer, winter 2014

9. Map showing static water-level altitudes in the deep part of the Equus Beds aquifer, winter 2014

10. Map showing water-level altitudes in the shallow part of the Equus Beds aquifer, summer 2012

11. Map showing water-level altitudes in the deep part of the Equus Beds aquifer, summer 2012

12. Graph showing average measured water-level changes in the Equus Beds aquifer in the shallow part of the aquifer since predevelopment and in the shallow and deep parts of the aquifer since 1993

13. Graph showing storage-volume changes since predevelopment and since 1993 in the study area, the basin storage area, and the central part of the study area

14. Map showing static water-level changes in the shallow part of the Equus Beds aquifer, predevelopment to winter 2014

15. Graph showing annual groundwater use in the central part of the study area and in the rest of the study area and average annual precipitation in the study area, 1988 through 2012

16. Map showing water-level changes in the shallow part of the Equus Beds aquifer, predevelopment to summer 2012

17. Map showing static water-level changes in the shallow part of the Equus Beds aquifer, 1993 to winter 2014

18. Map showing water-level changes in the shallow part of the Equus Beds aquifer, 1993 to summer 2012

19. Map showing water-level changes in the deep part of the Equus Beds aquifer 1993 to summer 2012

\section{Tables}

1. Streamgages and low-head dams in and near the study area, south-central Kansas ....9

2. Precipitation stations in and near the study area, south-central Kansas

3. Average water-level changes, storage-volume changes, and total aquifer storage volume in the Equus Beds aquifer near Wichita, south-central Kansas, predevelopment to winter 2014

1-1. Measured and interpolated water-level altitudes in the Equus Beds aquifer, predevelopment, 1993, winter 2012, summer 2012, winter 2013, and winter 2014 


\section{Conversion Factors}

\begin{tabular}{|c|c|c|}
\hline Multiply & By & To obtain \\
\hline \multicolumn{3}{|c|}{ Length } \\
\hline inch (in.) & 2.54 & centimeter $(\mathrm{cm})$ \\
\hline foot $(\mathrm{ft})$ & 0.3048 & meter $(\mathrm{m})$ \\
\hline mile (mi) & 1.609 & kilometer $(\mathrm{km})$ \\
\hline \multicolumn{3}{|c|}{ Area } \\
\hline acre & 4,047 & square meter $\left(\mathrm{m}^{2}\right)$ \\
\hline acre & 0.4047 & hectare (ha) \\
\hline acre & 0.004047 & square kilometer $\left(\mathrm{km}^{2}\right)$ \\
\hline square mile $\left(\mathrm{mi}^{2}\right)$ & 259.0 & hectare (ha) \\
\hline square mile $\left(\mathrm{mi}^{2}\right)$ & 2.590 & square kilometer $\left(\mathrm{km}^{2}\right)$ \\
\hline \multicolumn{3}{|c|}{ Volume } \\
\hline acre-foot (acre-ft) & 1,233 & cubic meter (m3) \\
\hline acre-foot (acre-ft) & 0.32581 & million gallons (Mgal) \\
\hline \multicolumn{3}{|c|}{ Flow rate } \\
\hline cubic foot per second $\left(\mathrm{ft}^{3} / \mathrm{s}\right)$ & 0.02832 & cubic meter per second $\left(\mathrm{m}^{3} / \mathrm{s}\right)$ \\
\hline million gallons per day $(\mathrm{Mgal} / \mathrm{d})$ & 0.04381 & cubic meter per second $\left(\mathrm{m}^{3} / \mathrm{s}\right)$ \\
\hline
\end{tabular}

Temperature in degrees Fahrenheit $\left({ }^{\circ} \mathrm{F}\right)$ may be converted to degrees Celsius $\left({ }^{\circ} \mathrm{C}\right)$ as follows: ${ }^{\circ} \mathrm{C}=\left({ }^{\circ} \mathrm{F}-32\right) / 1.8$

Vertical coordinate information is referenced to the North American Vertical Datum of 1988 (NAVD 88)

Horizontal coordinate information is referenced to the North American Datum of 1983 (NAD 83) Altitude, as used in this report, refers to distance above the vertical datum. 


\title{
Status of Groundwater Levels and Storage Volume in the Equus Beds Aquifer near Wichita, Kansas, 2012 to 2014
}

\author{
By Cristi V. Hansen, Joshua A. Whisnant, and Jennifer L. Lanning-Rush
}

\section{Abstract}

Development of the Wichita well field in the Equus Beds aquifer in southwest Harvey County and northwest Sedgwick County began in the 1940s to supply water to the city of Wichita. The decline of water levels in the Equus Beds aquifer was noted soon after the development of the Wichita well field began. Development of irrigation wells began in the 1960s.

City and agricultural withdrawals led to substantial water-level declines. Water-level declines likely enhanced movement of brines from past oil and gas activities near Burrton, Kansas, as well as natural saline water from the Arkansas River into the Wichita well field area. Large chloride concentrations may limit use, or require the treatment of water from the well field for irrigation or public supply. In 1993, the city of Wichita adopted the Integrated Local Water Supply Program to ensure an adequate water supply for the city through 2050 and manage effectively the part of the Equus Beds aquifer Wichita uses. The Integrated Local Water Supply Program uses several strategies to do this, including the Equus Beds Aquifer Storage and Recovery project. The purpose of the Aquifer Storage and Recovery project is to store water in the aquifer for later recovery, and help protect the aquifer from encroachment of a known oil-field-brine plume near Burrton and saline water from the Arkansas River. Since 1940, the U.S. Geological Survey, in cooperation with the city of Wichita, has monitored changes in the Equus Beds aquifer as part of Wichita's effort to manage this resource effectively.

Average water-level changes since predevelopment (before substantial pumpage began in the area) for winter 2012, summer 2012, winter 2013, and winter 2014 generally indicate greater declines in the central part of the study area than in either the basin storage or entire study area. In contrast, average water-level rises since 1993 for winter 2012, summer 2012, winter 2013, and winter 2014 were greater for the central part of the study area than for either the basin storage area or entire study area. This indicates the central part of the study area had more post-1993 water-level recovery than did the rest of the study area. In the central part of the study area, city water use decreased by about 40 percent, and irrigation water use increased by about 3 percent compared to pre-1993 peaks in 1992 and 1991, respectively, whereas irrigation water use outside the central part of the study area increased by about 24 percent from the pre-1993 peak in 1991. Part of the larger increase in irrigation pumpage probably was a result of drought-term and multiyear flex account permits, which were estimated to account for about 8 and 4 percent of irrigation pumpage in the study area in 2011 and 2012.

There was a larger percentage storage-volume increase since 1993 in the central part of the study area than in either the basin storage area or the entire study area. Storage-volume in the central part of the study area during winter 2012, summer 2013, winter 2013, and winter 2014 recovered about 46,300 acre-feet or more compared to the storage volume in 1993. In summer 2012 and winter 2013, the storage-volume increase since 1993 was larger in the central part of the study area than in the entire study area, indicating the storagevolume increases in the central part of the study area offset decreases in storage volume in the rest of the study area. The larger increase in storage volume in the central part of the study area than in the rest of the study area probably was because of the Integrated Local Water Supply Program strategy that reduced city pumpage from the Equus Beds aquifer by about 40 percent. The current (winter 2014) storage volumes in the entire study area and the central part of the study area are about 94 and 96 percent of their respective predevelopment storage volumes or about 3,067,000 and 962,000 acrefeet, respectively.

\section{Introduction}

Development of the Wichita well field in the Equus Beds aquifer in southwest Harvey County and northwest Sedgwick County began in the 1940s to supply water to the city of Wichita, the largest city in Kansas (fig. 1; Williams and Lohman, 1949; Gibson, 1998; U.S. Census Bureau, 2012). The other primary use of water from the Equus Beds aquifer is crop irrigation in this agriculturally dominated part of southcentral Kansas (Rich Eubank, Kansas Department of Agriculture, Division of Water Resources, oral commun., 2008). Soon after development of the Wichita well field began, water levels in the Equus Beds aquifer began to decline (Williams and Lohman, 1949). Large-scale development of irrigation wells 
began in the 1960s. City and agricultural withdrawals have led to substantial declines. As water levels in the Equus Beds aquifer decline, the volume of water stored in the Equus Beds aquifer decreases, and less water is available to supply future needs. Water-level declines in and near the well field increase the groundwater gradient toward the well field, and likely cause movement or increased movement of brines from past oil and gas activities near Burrton, Kans., as well as natural saline water from the Arkansas River (fig. 1), into the well field area. Further movement into the well field area of these waters with large chloride concentrations may limit use or may require treatment of water from the well field area for irrigation or public supply (Ziegler and others, 2010). Since 1940, the U.S. Geological Survey (USGS), in cooperation with the city of Wichita, has monitored changes in water levels and the resulting changes in storage volume in the Equus Beds aquifer as part of Wichita's effort to manage this resource effectively.

In 1993, the city of Wichita adopted the Integrated Local Water Supply Program (ILWSP) to ensure an adequate water supply for the city through the year 2050 and as part of its effort to effectively manage the part of the Equus Beds aquifer it uses (City of Wichita, [2007?], 2008; Desilva and Ary, 2011; Warren and others, 1995). The ILWSP uses several strategies to do this including the following: (1) having greater reliance on other sources of water from outside the study area [for example, Cheney Reservoir (fig. 1), the Bentley Well Field southwest of the Arkansas River, and Wichita's Local Well Field at the confluence of the Arkansas and Little Arkansas Rivers; locations not shown on figures]; (2) encouraging conservation; and (3) developing the Equus Beds Aquifer Storage and Recovery (ASR) project with a designed artificialrecharge capacity of as much as 100 million gallons per day (Mgal/d; City of Wichita, [2007?], 2008; Desilva and Ary, 2011). The purpose of the Equus Beds ASR project is to store and later recover groundwater, and to help protect that part of the Equus Beds aquifer used by the city from the encroachment of a known oil-field-brine plume near Burrton, Kans., and saline water from the Arkansas River (fig. 1; Ziegler and others, 2010). In 2007, the city of Wichita began using the Phase I facilities of the Equus Beds ASR project to increase long-term (more than 50 years) sustainability of the Equus Beds aquifer through large-scale artificial recharge (City of Wichita, [2007?]; Desilva and Ary, 2011). The ASR project uses water from the Little Arkansas River-pumped either from the river directly or from wells in the riverbank that obtain their water from the river by induced infiltration-as the source of artificial recharge to the Equus Beds aquifer (fig. 1; City of Wichita, [2007?]). For Phase I, the water pumped directly from the Little Arkansas River was treated to reduce sediment and remove atrazine before being recharged to the Equus Beds aquifer through recharge basins; water pumped from wells in the riverbank does not receive additional treatment before being recharged to the Equus Beds aquifer through recharge basins or wells (Debra Ary, city of Wichita, written commun., 2012). Phase II recharge facilities began operation in April 2013 and treat water withdrawn from the Little Arkansas River using ultrafiltration membranes and advanced oxidation techniques. The treated water can then be recharged into spreading basins or recharge wells throughout the area, and stored in the Equus Beds aquifer for future use (Debra Ary, city of Wichita, written commun., 2012).

\section{Purpose and Scope}

The purpose of this report is to document the status of groundwater levels and storage volumes in the Equus Beds aquifer for winter 2012, summer 2012, winter 2013, and winter 2014. Specifically, the following are documented: (1) the water-level altitudes in the shallow and deep parts of the Equus Beds aquifer; (2) the water-level and storagevolume changes in the shallow part of the Equus Beds aquifer since predevelopment (generally before September 1940 when substantial pumpage began in the study area) and 1993; and (3) water-level changes in the deep part of the Equus Beds aquifer since 1993. Information in this report can be used to document and improve understanding of water-resource management practices on water supplies in the Equus Beds aquifer, which is an important source of water for the city of Wichita and the surrounding area.

\section{Description of Study Area}

The study area covers about 189 square miles $\left(\mathrm{mi}^{2}\right)$ and is northwest of Wichita in Harvey and Sedgwick Counties (fig. 1). It is mostly bordered on the southwest by the Arkansas River and on the east by the Little Arkansas River (fig. 1). Land surface in the study area typically slopes gently toward the major streams from an altitude of about 1,510 feet (ft) above the North American Vertical Datum of 1988 (NAVD 88) in the northwest to a low of about $1,325 \mathrm{ft}$ in the southeast.

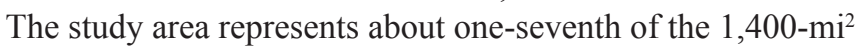
Equus Beds aquifer area (fig. 1). About one-third of the pumpage from the Equus Beds aquifer occurs in the study area (Kansas Department of Agriculture, 2011). Irrigation and city use dominate pumpage from the Equus Beds aquifer in the study area (Hansen and Aucott, 2010). Pumpage from the study area in 2012 (latest year for which pumpage is available) was about 40,800 acre-feet (acre-ft) for irrigation and about 21,600 acre-ft for the city of Wichita (Kansas Department of Agriculture, and Kansas Geological Survey, 2014).

The about 141-mi ${ }^{2}$ Basin Storage Area (BSA; fig. 1) is defined as the recharge-credit accounting area by Wichita's Equus Beds ASR permits. The BSA is used by the city of Wichita, the Equus Beds Groundwater Management District Number 2 (GMD2), and the Kansas Department of Agriculture, Division of Water Resources (KDA DWR) to estimate the location of artificially recharged water in the Equus Beds aquifer, and to determine where and how much of this recharged water can be used in the future by Wichita (Kansas Department of Agriculture, 2005). 


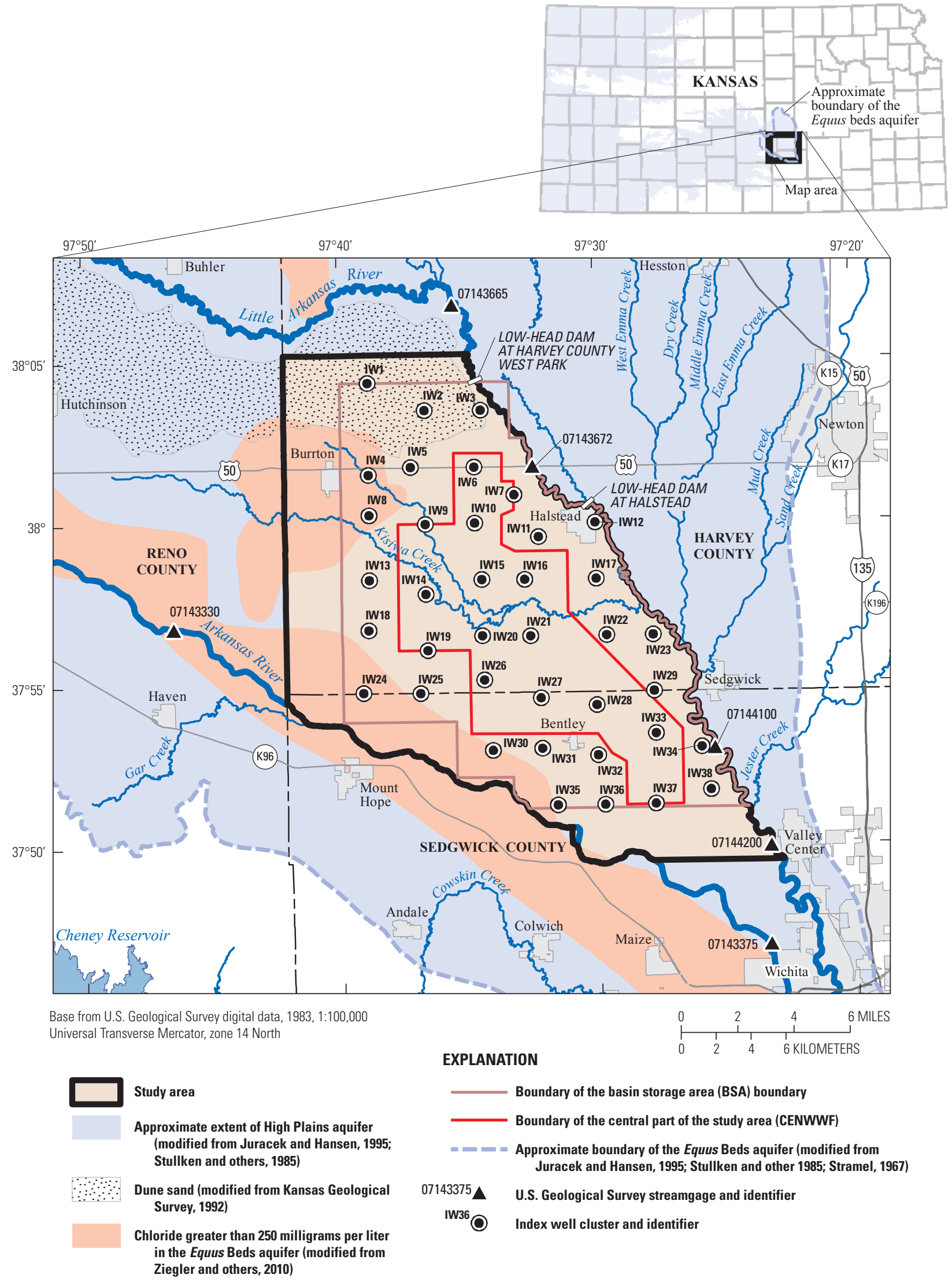

Figure 1. Location of study area near Wichita, south-central Kansas (modified from Aucott and Myers, 1998). 
The central part of the study area (CENWWF as identified by Kelly and others (2013); fig. 1) covers about $55 \mathrm{mi}^{2}$, or less than one-third of the study area, and is the historic center of pumping in the study area. The CENWWF includes wells used to supply water to the city of Wichita and many wells used for irrigation (Kansas Department of Agriculture and Kansas Geological Survey, 2014). Pumpage from the CENWWF in 2012 was about 11,700 acre-ft for irrigation and about 21,400 acre-ft for the city of Wichita (Kansas Department of Agriculture and Kansas Geological Survey, 2014).

South-central Kansas has a continental climate characterized by large variations in seasonal temperatures, moderate precipitation, and windy conditions. In Wichita, long-term daily normal temperatures for 1981-2010 ranged from 32.2 degrees Fahrenheit $\left({ }^{\circ} \mathrm{F}\right)$ in January to $81.1^{\circ} \mathrm{F}$ in July (National Oceanic and Atmospheric Administration, 2014b). The long-term (1940-2013) annual average precipitation at weather stations in or near the study area (at Bentley, Halstead, Hutchinson, Mount Hope, Newton, Sedgwick, and Wichita, Kans.) is 31.38 inches (in.; National Oceanic and Atmospheric Administration, 2014a; fig. 2A). Annual average precipitation values ranged from about 46 to 153 percent of the long-term average during 1940 through 2013. The extent and severity of periods of greater- or less-than average precipitation are indicated distinctly by the 5-year moving average (fig. $2 A$ ). Average annual precipitation in the study area in 2011, 2012, and 2013 was $20.84,22.96$, and 39.56 in. (fig. $2 A$ ), or 66, 73, and 126 percent of the long-term average. When precipitation is equal to the long-term average, irrigation use in the study area from the Equus Beds aquifer is expected to be about 32,000 acre-ft per year (fig. 3). In dry years when precipitation in the study area is only about 75 percent or less of the long-term average, irrigation water use generally is expected to increase by at least 20 percent to about 38,000 acre-ft or more (fig. 3).

Precipitation in the study area affects streamflow in the Little Arkansas River, which Wichita uses as its source of water for artificial recharge. The much less than average precipitation during 2011, 2012, and the first part of 2013 (fig. $2 A$ ) decreased flow in the Little Arkansas River, and Wichita's ability to divert water for artificial recharge. Wichita can divert water at Phase I ASR sites from the Little Arkansas River when streamflow measured at USGS gage on the Little Arkansas River at Highway 50 near Halstead (07143672; fig. 1) is greater than 57 cubic feet per second $\left(\mathrm{ft}^{3} / \mathrm{s}\right)$ during April 1 through September 30 or greater than $20 \mathrm{ft}^{3} / \mathrm{s}$ during October 1 through March 31 (Kansas Department of Agriculture, 2005). Mean daily streamflow in the Little Arkansas River at Highway 50 near Halstead exceeded the conditions required for artificial recharge for about 42 percent of the period of record (May 1, 1995 through December 31, 2013; U.S. Geological Survey, 2014a). However, artificial recharge flow conditions in the Little Arkansas River at Highway 50 near Halstead were exceeded for only about 8 percent of the time from April 1, 2011 through September 30, 2013 (U.S. Geological Survey, 2014a).
Wichita can divert water from the Little Arkansas River at the ASR Phase II site near Sedgwick only if flow in the stream is maintained at $30 \mathrm{ft}^{3} / \mathrm{s}$ or greater at the USGS gage on the Little Arkansas River at Valley Center (07144200; Kansas Department of Agriculture, 2009), which is near the downstream edge of the study area (fig. 1). Mean daily streamflow in the Little Arkansas River at Valley Center exceeded $30 \mathrm{ft}^{3} / \mathrm{s}$ for about 77 percent of the period of record (June 10, 1922, through December 13, 2013; U.S. Geological Survey, 2014a). In contrast, mean daily streamflow in the Little Arkansas River at Valley Center exceeded $30 \mathrm{ft}^{3} / \mathrm{s}$ for only about 30 percent of the time from April 1, 2011 through March 31, 2013 (U.S. Geological Survey, 2014a). Diversions at the ASR Phase II site are additionally restricted by freezing temperatures; therefore, diversions at the ASR Phase II site are confined to April 15 through October 15. Mean daily streamflow exceeded $30 \mathrm{ft}^{3} / \mathrm{s}$ only about 14 percent of the time between April 15 through October 15 in 2011 and 2012 (U.S. Geological Survey, 2014a).

\section{Hydrogeology of the Study Area}

The Equus Beds aquifer is the easternmost extension of the High Plains aquifer in Kansas (fig. 1; Stullken and others, 1985; Hansen and Aucott, 2001). The Equus Beds aquifer covers about 1,400 $\mathrm{mi}^{2}$ in Kansas or about 5 percent of the about 30,900 $\mathrm{mi}^{2}$ covered by the High Plains aquifer in Kansas (fig. 1). The Equus Beds aquifer is an important source of water because of the generally shallow depth to the water table, the large saturated thickness, generally good hydraulic conductivity, and generally good water quality.

The Equus Beds aquifer (fig. 1) primarily consists of Quaternary-age alluvial deposits, locally known as the Equus beds, with some dune sand and loess (Myers and others, 1996). The alluvial deposits are as thick as $250 \mathrm{ft}$ in the study area near the Arkansas River (Leonard and Kleinschmidt, 1976). The Equus beds primarily consist of sand and gravel interbedded with clay or silt, but locally may consist primarily of clay with thin sand and gravel layers (Lane and Miller, 1965; Myers and others, 1996). North of U.S. Highway 50 and south of the Little Arkansas River in the study area, an area of dune sands (fig. 1) is underlain by thick clay layers that restrict the downward movement of water in the Equus Beds aquifer and create the confined to semiconfined conditions in the deep Equus Beds aquifer layer (Kelly and others, 2013). The about $700-\mathrm{ft}$ thick Permian-age Wellington Formation underlies the Equus beds in the study area and forms a bedrock confining unit (Bayne, 1956; Myers and others, 1996). Using the groundwater flow model of Kelly and others (2013), the total storage volume (the amount of water available for use) of the Equus Beds aquifer was estimated at about 3,192,000 acre-ft for the study area, 2,400,000 acre-ft for the BSA, and 1,025,000 acre-ft for the CENWWF (Hansen and others, 2013). 
A. Precipitation

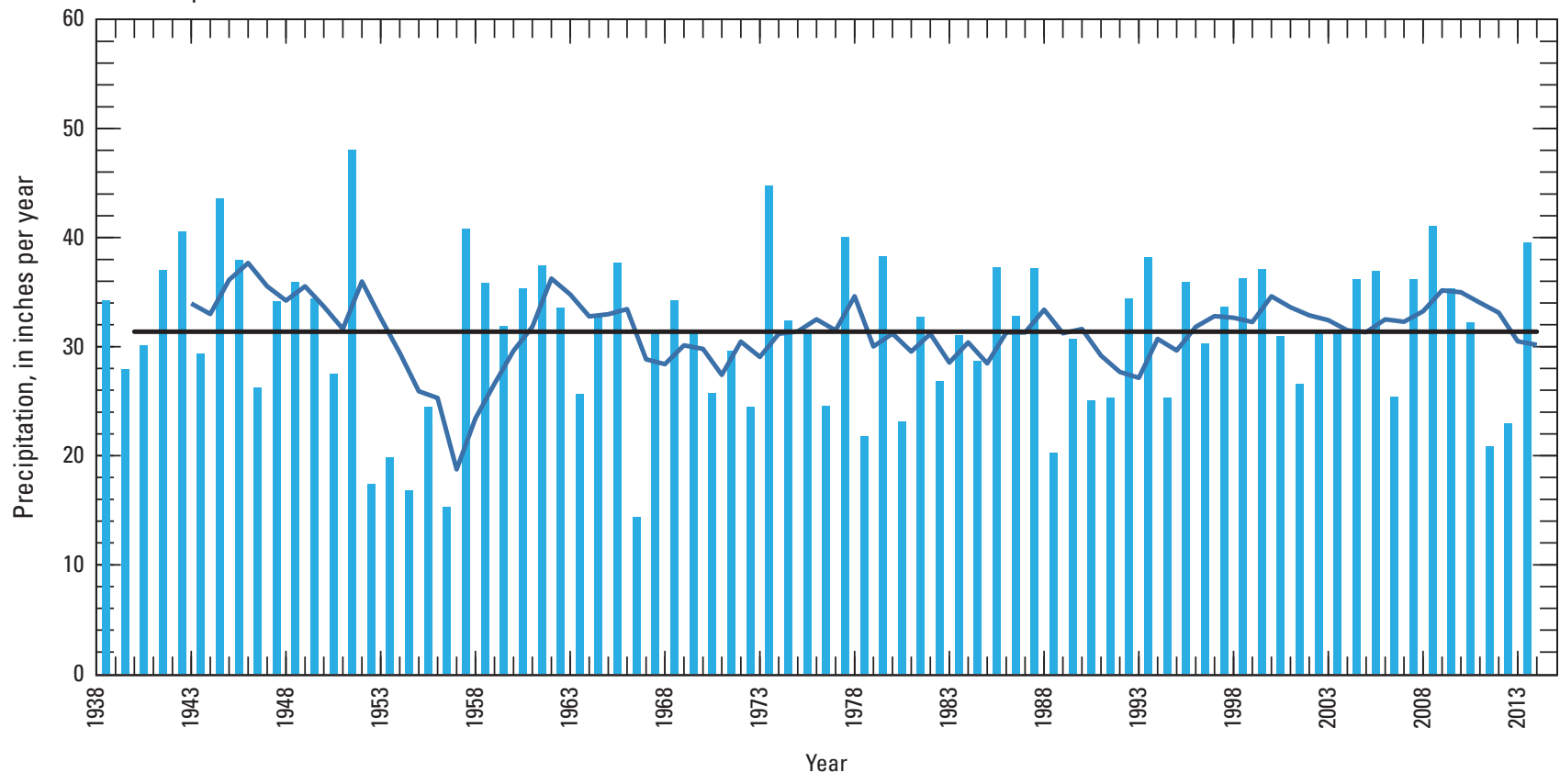

EXPLANATION

Average annual precipitation-Average for weather stations in or near Bentley,

Halstead, Hutchinson, Mount Hope, Newton, Sedgwick, and Wichita, Kansas

5-year moving average of annual precipitation

— Long-term (1940 through 2013) average annual precipitation, 31.38 inches

B. Water use for city of Wichita public supply and for agricultural irrigation

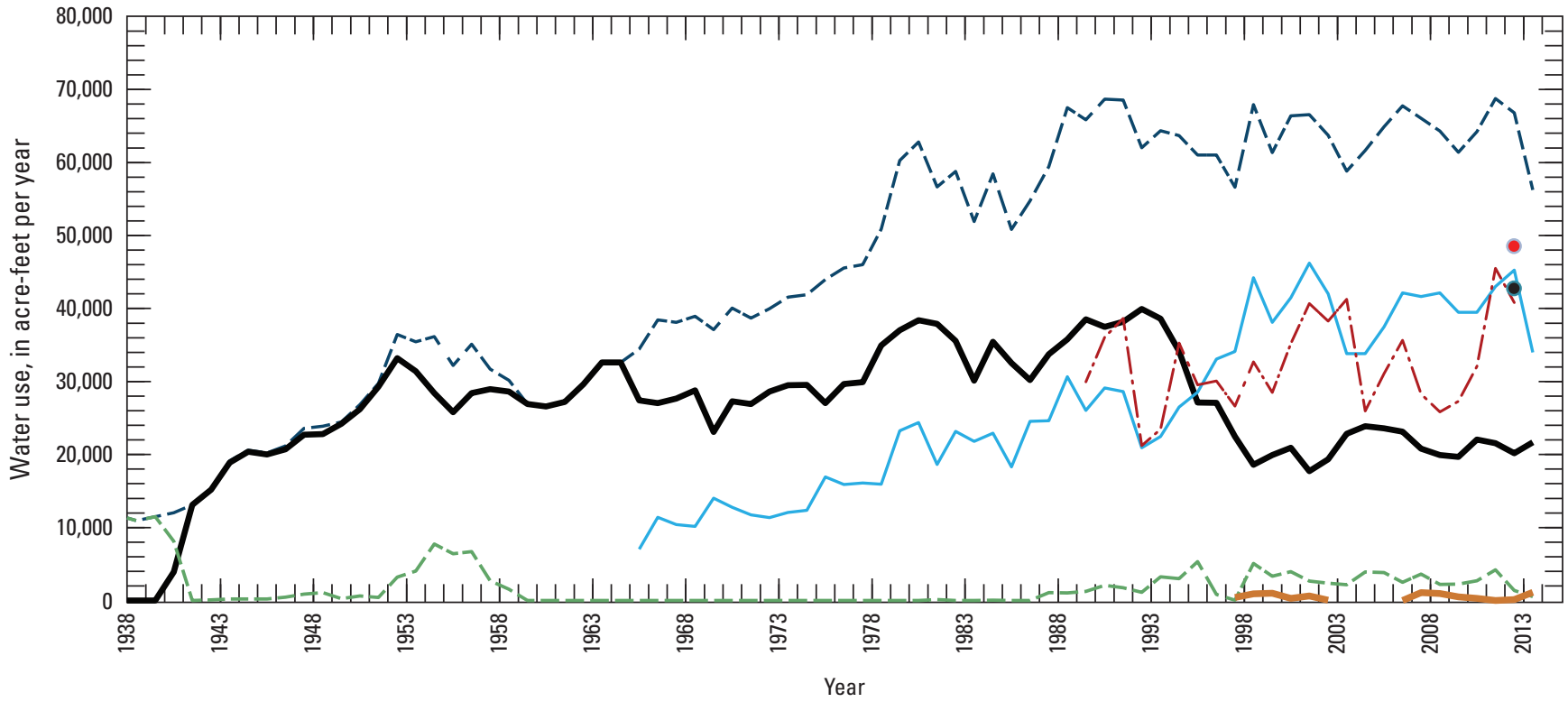

EXPLANATION

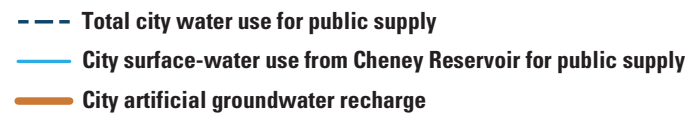

- Permitted groundwater use for agricultural irrigation in study area in 2013

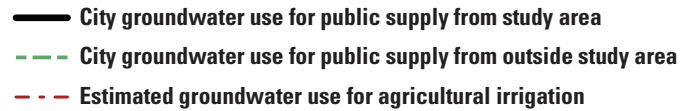

Estimated groundwater use for agricultural irrigation

- Permitted groundwater use for city public supply in study area in 2013

Figure 2. Relation of $A$, precipitation; and $B$, water use for the city of Wichita public supply and agricultural irrigation in the study area, 1938 through 2013. [Precipitation data are from National Oceanic and Atmospheric Administration (2014a); water-use data are from Wichita Water Department [1959?], Stramel (1956, 1967), G.T. Blain (written commun., city of Wichita, 1997), Megan Schmeltz (written commun., city of Wichita, 2009), Kansas Department of Agriculture and Kansas Geological Survey (2014), Kansas Department of Agriculture (unpub. data, 2014), and U.S. Geological Survey (2014).] 


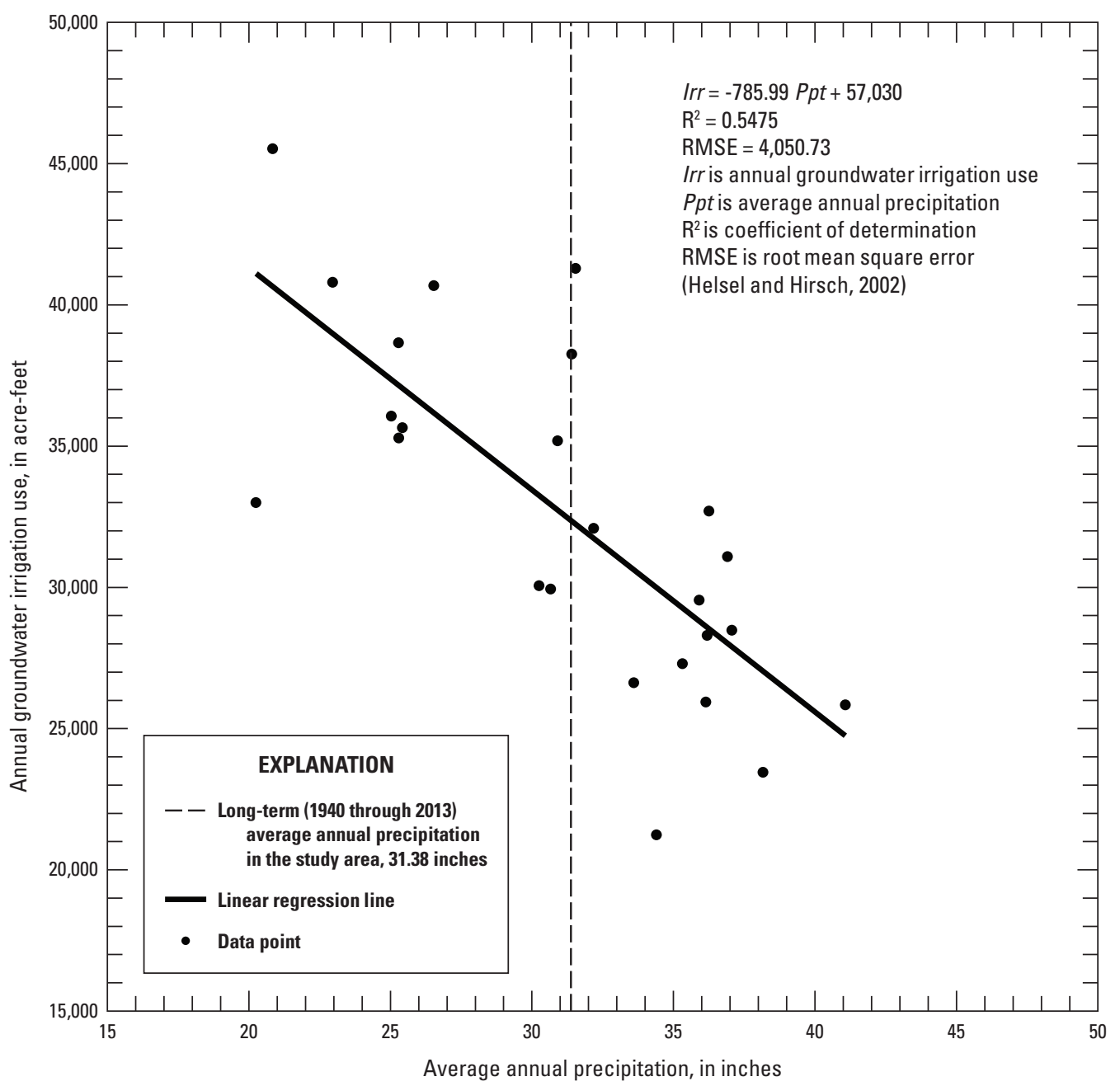

Figure 3. Statistical relation between annual groundwater irrigation use and average annual precipitation in the study area, 1988 through 2012. [Precipitation data are from National Oceanic and Atmospheric Administration (2014a); water-use data are from Kansas Department of Agriculture and Kansas Geological Survey (2014).]

Near the Arkansas River and in the west part of the study area (fig. 1), the water table in the Equus Beds aquifer can be less than $10 \mathrm{ft}$ below land surface. Farther from the Arkansas River and near the Little Arkansas River (fig. 1), the water table can be at a greater depth (as much as $50 \mathrm{ft}$ below land surface in January 2012) depending on the altitude of the land surface and the amount of water-level decline that has been caused by groundwater withdrawals. The saturated thickness of the Equus Beds aquifer within the study area ranges from about $75 \mathrm{ft}$ near the Little Arkansas River to almost $250 \mathrm{ft}$ near the Arkansas River where the lowest areas of the underlying bedrock surface occur (Spinazola and others, 1985). The Equus Beds aquifer is unconfined, but the presence of clay layers has resulted in semiconfined conditions in some areas (Spinazola and others, 1985; Stramel, 1967). These semiconfined conditions may have resulted in the substantial waterlevel and water-quality differences in the shallow and deep parts of the Equus Beds aquifer in some parts of the study area
(Stramel, 1956; Whittemore, 2007, 2012; and Ziegler and others, 2010). These substantial differences, along with a need to monitor the long-term effects of artificial recharge on the shallow and deep parts of the Equus Beds aquifer, led to development of separate water-level altitude maps of the shallow and deep parts of the Equus Beds aquifer.

\section{Previous Studies}

The Equus Beds aquifer (fig. 1) has been extensively studied because of its importance as a source of water for cities, agriculture, and industry. As noted by Kelly and others (2013), these previous studies include the following: Williams and Lohman (1949), Stramel (1956, 1962a, 1962b, 1967), Petri and others (1964), Sophocleous (1983), Spinazola and others (1985), Pruitt (1993), Myers and others (1996), Aucott and Myers (1998), Aucott and others (1998), Ziegler 
and others (1999, 2010), Hansen and Aucott (2001, 2004, 2010), Hansen (2007, 2009a, 2009b, 2011a, 2011b, 2012), and Hansen and others (2013). In addition, Burns and McDonnell Engineering, Inc. (Kansas City) has worked with the city of Wichita to determine the location and amount of the ASR recharge credits the city of Wichita is permitted to pump from the Equus Beds aquifer as part of the annual accounting required by KDA DWR.

\section{Methods}

This section describes the methods used to define the shallow and deep parts of the Equus Beds aquifer. The sources of measured groundwater and surface-water levels, precipitation and water-use data, and estimates of specific yield are discussed. The techniques used to compute and estimate water-level altitudes, water-level changes, and storage-volume changes are described.

\section{Shallow and Deep Parts of the Equus Beds Aquifer}

Wells completed and screened in the Equus Beds aquifer were assigned to either the shallow or deep parts of the Equus Beds aquifer based on the depth of the bottom of the well casing or of the screened interval to describe differences between the water levels in the shallow and deep parts of the Equus Beds aquifer. These assignments were based on Equus Beds GMD2 aquifer zone designations, and on well completion and screen depths. GMD2 has identified as many as four aquifer zones (designated AA, A, B, and C, in order of descending depth) within the Equus Beds aquifer where there are competent clay layers separating the zones (Tim Boese, Equus Beds Groundwater Management District Number 2, written commun., 2009). The A, B, and C zones are similar to the upper, middle, and lower aquifer units defined by Myers and others (1996); the AA zone is of more limited areal extent and would be considered part of the upper aquifer unit. GMD2 monitoring wells generally are in clusters (closely spaced wells screened at different depths) with each well screened in a different aquifer zone. For this report, wells designated by GMD2 as completed in zones $\mathrm{A}$ and $\mathrm{C}$ were assigned to the shallow and deep parts of the Equus Beds aquifer, respectively; no wells designated as completed in zone AA were used in this study. A few wells designated by GMD2 as being in zone B that were deemed to be in the same zone as the nearby BSA deep index wells were used to supplement interpretation of the deep water-level altitude map.

The city of Wichita has monitoring wells, some of which are in clusters, which have not been assigned to GMD2 zones. The shallower well in each city well cluster was assumed to be in and assigned to the shallow part of the Equus Beds aquifer; the deeper well in each cluster was assumed to be in and assigned to the deep part of the Equus Beds aquifer. Ziegler and others (2010) used a depth of $80 \mathrm{ft}$ as the dividing point between the shallow and deep parts of the Equus Beds aquifer. An analysis of the GMD2 and city of Wichita well clusters in the study area by Hansen (2011b) indicated about 90 percent of the GMD2 zone A wells and shallower wells in city well clusters were completed and screened to a depth of $80 \mathrm{ft}$ or less; about 90 percent of the GMD2 zone $\mathrm{C}$ wells and deeper wells in city well clusters were completed and screened to a depth of greater than $80 \mathrm{ft}$. Thus, use of the $80 \mathrm{ft}$ depth as the dividing point between shallow and deep parts of the Equus Beds aquifer was reasonable when assigning the city of Wichita monitoring wells that were not in clusters into either the shallow or deep parts of the Equus Beds aquifer. Examination of well and screen depths and of water-level hydrographs led in a few cases to assigning more than one well in a cluster to the same part of the Equus Beds aquifer. In most of these cases, both wells were less than $80 \mathrm{ft}$ deep and were assigned to the shallow part of the Equus Beds aquifer.

\section{Water Levels}

The city of Wichita's historic monitoring and production wells have been used for monitoring water levels in the Equus Beds aquifer for decades (many since the late 1930s; Stramel, 1956). Some of the historic wells in the CENWWF were replaced in 2009 through 2010 as part of Phase II of the ASR project. The BSA index (IW) monitoring wells (fig. 1) were installed in 2001 and 2002 to monitor the effects of artificial recharge on water quality and water levels in the Equus Beds aquifer, and to determine if there are water-quality differences between the shallow and deep parts of the Equus Beds aquifer (Andrew Ziegler, U.S. Geological Survey, oral commun., 2003). The ASR Phase I monitoring wells were installed to monitor the potential effects of artificial recharge around the six ASR Phase I artificial recharge sites. The ASR Phase II monitoring wells were installed in 2009 and 2010 to monitor the potential effects of artificial recharge on water quality in the Equus Beds aquifer near Phase II artificial recharge sites as required by the Kansas Department of Health and Environment Class V permit (Andrew Ziegler, U.S. Geological Survey, written commun., 2014). The GMD2 monitoring wells were installed for GMD2 beginning in 1978 or are existing wells used by GMD2 to monitor the Equus Beds aquifer.

\section{Water-Level Measurements}

Water levels in the Equus Beds aquifer were measured from January 3, 2012, through January 15, 2014, in 224 city of Wichita historic monitoring or production wells, or their replacements; 76 IW monitoring wells; 39 Phase I and II monitoring wells; and 54 GMD2 monitoring wells. These data were used to represent water-level conditions in winter 2012, summer 2012, winter 2013, and winter 2014 in the shallow and deep parts of the Equus Beds aquifer in the study area. Water levels from an additional 19 Wichita historic monitoring wells and 94 GMD2 monitoring wells in the shallow and deep parts of the Equus Beds aquifer outside the study area 
were used to improve the analyses and interpretations near the boundaries of the study area, but are not discussed or presented in this report. Not all wells were measured during every time period, and not all wells measured in a given time period were used in this report. City of Wichita personnel measured water levels in the historic monitoring wells at least quarterly and measured water levels monthly in many of the historic monitoring wells in the CENWWF. GMD2 personnel measured water levels in the IW and GMD2 and monitoring wells. The IW monitoring wells were measured quarterly by GMD2. Some of the GMD2 monitoring wells only were measured annually during the winter months (December through March) of the year after the irrigation season had ended; other wells were measured by GMD2 on a quarterly or monthly basis. USGS personnel measured water levels in the remaining Phase I and II monitoring wells. Water levels in some of the IW and Phase I monitoring wells also were measured by the USGS using multisensor monitors that continuously collect physical properties including water-level altitude. All agencies used standard water-level measurement techniques that are similar to USGS methods described in Cunningham and Schalk (2011). The historic monitoring well data are on file, in paper and electronic form, with the Public Works and Utilities Department in Wichita; the IW and GMD2 monitoring well data collected by GMD2 are stored in the Kansas Geological Survey Water Information Storage and Retrieval Database (WIZARD; Kansas Geological Survey, 2014). Well data collected by the USGS are stored in the USGS National Water Information System (NWIS) database (U.S. Geological Survey, 2012). All of the measured water-level data used in this report also are stored in NWIS.

For winter 2012, groundwater levels were measured from December 1, 2011, through February 21, 2012, at 194 wells in the shallow part of the Equus Beds aquifer and from December 1, 2011, through February 1, 2012, at 170 wells in the deep part of the Equus Beds aquifer. For summer 2012, groundwater levels were measured from July 2, 2012, through September 25, 2012, at 190 wells in the shallow part of the Equus Beds aquifer and from July 2, 2012, through September 20, 2012, in 163 wells in the deep part of the Equus Beds aquifer. For winter 2013, groundwater levels were measured from November 30, 2012, through February 6, 2013, at 180 wells in the shallow part of the Equus Beds aquifer and from November 30, 2012, through February 6, 2013, at 145 wells in the deep part of the Equus Beds aquifer. For winter 2014, groundwater levels were measured from January 2, 2014, through January 8, 2014, at 223 wells in the shallow part of the Equus Beds aquifer and from January 2, 2014, through January 8, 2014, at 170 wells in the deep part of the Equus Beds aquifer.

\section{Data Quality and Limitations}

Most of the water-level data used in this report were collected for other purposes by the city of Wichita and GMD2 personnel. The quality of the water-level data for each well was evaluated by examining hydrographs summarizing all water-level data for each well. Questionable water levels were not used. Because the winter 2012, 2013, and 2014 water-level altitude maps represent static — not pumping — water-level conditions, water levels that were noted as being from pumping wells or near pumping wells were not used. For the winter 2012, 2013, and 2014 water-level altitude maps, wells whose hydrographs indicated that the water levels were affected by pumping also were excluded from use.

The summer 2012 water-level altitude maps represent stressed - not static — water-level conditions. Most of the monitoring wells used for this report are generally one-eighth to one-quarter of a mile or more from the nearest pumping well. However, water levels in most of the monitoring wells commonly decline more than $10 \mathrm{ft}$ during the irrigation season (May through August). As a result, some summer 2012 pumping-affected water levels were used because without them the distribution of data points would not have been dense enough to construct the summer 2012 water-level altitude maps.

The rasters used in this report were interpolated from the point data derived from the measured water levels and well locations. Rasters are areal grids of cells with a value assigned to each cell. The algorithms used by the program to generate the rasters generalized the point data (Esri, 2012). As a result, the value of the raster may not exactly match a measured value at the same location. Also, the contours generated from the raster may require some modification to match the measured point data. To reduce the potential for errors created by the use of rasterized data, a raster cell size of 10 meters by 10 meters was used.

\section{Water-Level Altitudes}

The water-level altitudes used in this report were stored as water-level altitudes (in NWIS) or calculated by subtracting the depth to water below land surface from the altitude of land surface. Land-surface altitudes at wells are those stored in NWIS and WIZARD. Land-surface altitudes referenced to the National Geodetic Vertical Datum of 1929 (NGVD 29) were converted to the NAVD 88; all water-level altitudes are referenced to the NAVD 88. Predevelopment and 1993 water-level altitudes used in this report were measured or interpolated values reported in Hansen and others (2013), or were interpolated from the rasters used by Hansen and others (2013). The water-level altitude was interpolated by intersecting the well's location with the appropriate raster (predevelopment or 1993) of the water-level altitude map of the appropriate part of the Equus Beds aquifer developed by Hansen and others (2013) and applying the water-level altitude of the raster at that location to the well. Measured and interpolated waterlevel altitudes used in this report are included in table 1-1 in the appendix.

The winter period was defined as December of the preceding year through February of the specified year. For example, winter 2012 contained water levels from December 2011 through February 2012. In the winter periods, preference was given to the water levels measured in January. If a 
January water level was measured when the well was noted as affected by pumping (either because the well or a nearby well was pumping), the water level was replaced by an unaffected water level from either December or February. If pumping affected all water-level measurements for winter, the well was excluded from the analysis. Wells measured only once during winter were not used if the hydrograph or the water-level altitude map indicated it was affected by pumping. Because of their importance to the monitoring of the ASR project, all the IW monitoring wells were used for the analysis even if an IW well's hydrograph indicated that the well might have been affected by pumping from nearby wells.

The summer 2012 period was defined as July through September 2012. In the summer 2012 period, preference was given to water levels measured in August 2012. If an August water level was measured when the well was noted as affected by pumping, the water level was replaced by a measurement from either July or September 2012. This replacement water level was used only if it was unaffected by pumping. If all the water levels for the period were noted as affected by pumping, the well was excluded from the analysis. If a well was only measured once during the summer 2012 period, the water level was used unless the water-level altitude map indicated it probably was greatly affected by pumping. All of the IW monitoring wells were used in the analysis.

Rasters of water-level altitudes were generated from the measured water levels and the water-level altitude contours created from these rasters. The measured winter 2012, summer 2012, winter 2013, or winter 2014 water-level altitudes; and the well locations were entered into ArcGIS, plotted on the water-level altitude map of their assigned part of the Equus Beds aquifer, and converted to a raster using ArcGIS Spatial Analyst's "Topo to Raster" command (Esri, 2012b). Rasters for the shallow and deep parts of the Equus Beds aquifer were then contoured using the ArcGIS Spatial Analyst's "Contour" command (Esri, 2012a), and plotted with the well data using a $5 \mathrm{ft}$ contour interval. Where needed, the machine-generated water-level altitude contours were modified to match the well data. Further constraints on the water-level altitude contours were that (1) all water-level altitude contours would remain below land surface except at known surface-water bodies; (2) the 2012, 2013, and 2014 water-level altitude contours for the deep part of the Equus Beds aquifer would remain below contours of the shallow part of the Equus Beds aquifer except at gaining streams or where the measured water levels from well clusters indicated otherwise; and (3) the 1993 static water-level altitude contours for the shallow and deep parts of the Equus Beds aquifer (Hansen and others, 2013) were used to guide the placement of the 2012, 2013, and 2014 contours. A new raster was generated from the measured points and revised contours. These rasters were used to estimate the water-level and storage-volume changes in study area.

Surface-water altitudes from six streamgages and two low-head dams (fig. 1; table 1) were used as additional data points to manually adjust contours in the shallow part of the Equus Beds aquifer. Mean daily surface-water altitudes at the midpoint of the period when most of the groundwater levels were measured for each time period were used. The surfacewater altitudes were obtained from NWIS (U.S. Geological Survey, 2014a) for the streamgages; the altitudes of the tops of the low-head dams (Trudy Bennett, U.S. Geological Survey, written commun., 2009) were used as the surfacewater altitude at the low-head dams. The surface-water altitudes of the two low-head dams were not used for the summer 2012 because flow in the Little Arkansas River was 0.02 and $0.00 \mathrm{ft}^{3} / \mathrm{s}$ at streamgages 07143665 and 07143673 (U.S. Geological Survey, 2013), which are upstream from the low-head dams.

Table 1. Streamgages and low-head dams in and near the study area, south-central Kansas.

[USGS, U.S. Geological Survey; NAVD 88, North American Vertical Datum of 1988; --, not applicable; e, estimated]

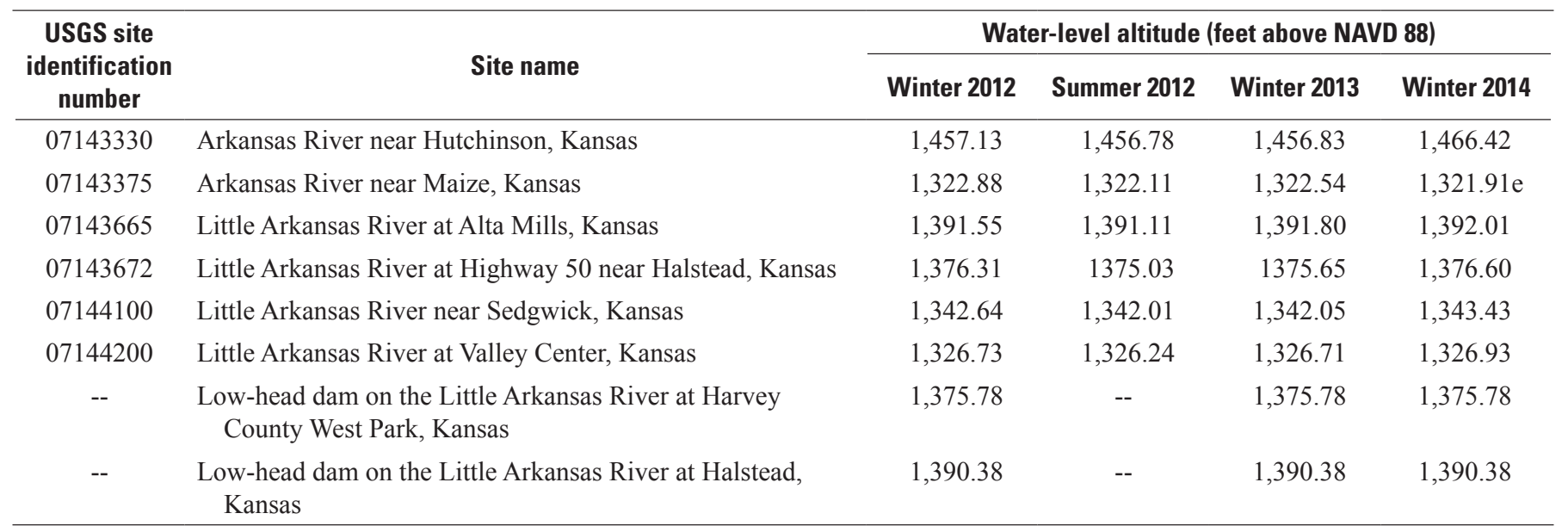




\section{Water-Level Change}

The water-level change maps in this report were developed using the method described by Hansen and others (2013). The method involved subtraction of water-level altitude rasters developed from measured water-level altitudes for separate time periods. The water-level change was determined by subtracting the water-level altitude at the beginning of a time period from the water-level altitude at the end of the time period. The use of rasterized water-level altitude maps to generate water-level change maps allowed for a water-level change map that was more consistent with the water-level altitude maps and potentially more accurate than one based only on the smaller number of wells with measured water-level altitudes at both the beginning and end of the time period. Results of the raster subtractions were converted to contour maps, and the contours revised where necessary to honor the actual measured data and to make hydrologic sense.

The average water-level change from one period to another (for example, from predevelopment to winter 2012) was computed three ways. First, it was computed at wells with measured water levels in both periods; second, it was computed by including wells with measured water levels for the end of the period and interpolated water levels for the beginning of the period; and third, it was computed using the average water-level altitude change of the resulting raster subtraction.

When possible, static water levels from the shallow and deep parts of the Equus Beds aquifer were used in this study for determining water-level changes. Static water levels from the shallow part of the Equus Beds aquifer also were used for determining storage-volume changes in the Equus Beds aquifer. The stressed condition of the Equus Beds aquifer in summer 2012 precluded use of only static water levels for determining water-level and storage-volume changes.

\section{Specific Yield}

Specific yield is defined by Lohman (1972) as "the ratio of (1) the volume of water which the rock or soil, after being saturated, will yield by gravity to (2) the volume of rock or soil." A specific yield of 0.15 was used in this study as well as a previous study (Hansen and others, 2013) because it was within the range of most estimates and matched the specific yield used by a recent groundwater flow model of the Equus Beds aquifer (Kelly and others, 2013). The specific yield of 0.15 from the groundwater flow model was a product of the model calibration; that is, it was determined to produce simulated water levels that better matched observed water levels than did other values of specific yield. Specific yield can be used with the volume of water-level change to estimate the amount of increase or decrease in water available from storage in the Equus Beds aquifer.

\section{Total Aquifer Storage Volume}

The total aquifer storage volume was estimated using the groundwater flow model of Kelly and others (2013). The model multiplied the predevelopment thickness of the Equus Beds aquifer by the area of each cell, summed the volume of all the cells within a specified area, and then multiplied the result by the specific yield of 0.15 . Total aquifer storage volume for the Equus Beds aquifer in the study area, BSA, and CENWWF, based on the groundwater flow model results, was reported as about 3,192,000, 2,400,000, and 1,025,000 acre-ft by Hansen and others (2013).

\section{Aquifer Storage-Volume Change}

Aquifer storage-volume change for the purposes of this report is defined as the change in aquifer thickness multiplied by the area of the aquifer containing the change and by the specific yield of the aquifer. The change in aquifer storage volume is estimated in this manner instead of computing the difference between two total aquifer storage volumes because of the large uncertainty in the total aquifer storage volume and the amount of storage-volume change to date (2014) is small compared to the total aquifer storage volume. For example, the 202,000 acre-ft of storage-volume loss from predevelopment to 1993 (Hansen and others, 2013) is thought to represent the largest recorded storage-volume change to date because record to near-record low water levels were measured in 1993. However, this storage-volume change only represents about 6 percent of the about 3,192,000 acre-ft of total storage volume of the Equus Beds aquifer in the study area (Hansen and others, 2013).

In this report, the first step in the storage-volume-change calculation was creating a water-level change raster by subtracting the raster of the water-level altitudes at the beginning of the change period from the raster of the water-level altitudes at the end of the period. The resulting water-level change raster was converted to contours, plotted with the measured water-level changes at the wells, and the contours modified where needed to conform to the measured water-level changes and to make hydrologic sense. The revised contours and the measured water-level changes were used to create a new water-level-change raster. The area of each cell in the revised raster was multiplied by the water-level change for that cell; the resulting value for each cell multiplied by a specific yield of 0.15 estimated the storage-volume change in each raster cell. Storage-volume changes were summed for all the cells within a particular area to estimate the storage-volume change for that area. To avoid implying unsupported precision in the estimates of storage-volume change, the values were reported only to three significant figures. 


\section{Precipitation}

Precipitation for the study area was estimated as the arithmetic average of precipitation data from as many as nine weather stations in or near the study area. These weather stations are in or near Bentley (140750), Halstead (143366), Hutchinson (143926 and 143930), Mount Hope (145539), Newton (145744), Sedgwick (147313), and Wichita (148828 and 148830; table 2; cooperative station identifiers in parentheses). Only the station near Sedgwick was not active during 2011 through 2013 (table 2). Precipitation data for these stations are available from the National Oceanic and Atmospheric Administration (2014a). The 5-year moving average of precipitation (fig. $2 A$ ) was calculated as the average of the annual average precipitation for the study area for successive 5 -year periods with each successive period advanced by one year. The results were plotted at the end of each 5-year period. For example, results for the period of 2009 through 2013 were plotted at the end of 2013.

\section{Water-Use}

Water-use data were compiled by the KDA DWR from annual water-use reports submitted by persons and entities permitted to divert water in Kansas. Those who divert water for uses other than domestic, or who divert more than 15 acre-ft of water per year, are required to have a permit and to submit an annual water-use report. The information available from KDA DWR includes the location of the point of diversion, the amount of water diverted (in acre- $\mathrm{ft}$ ) for the year, and the type of use. The water-use data for 1989 through
2012 were available through the Water Information Management and Analysis System (WIMAS) online program of the KDA DWR at http://hercules.kgs.ku.edu/geohydro/wimas/ index.cfm.

\section{Water-Level Altitude Maps}

A water-level-altitude surface of an aquifer or of part of an aquifer indicates the height of the water surface above a datum (for example, NAVD 88), and the direction of flow within the aquifer or part of an aquifer. Where an aquifer is unconfined, the water-level altitude surface is the same as the water table. In general, water moves horizontally and vertically from areas of higher water-level altitudes towards lower water-level altitudes. Water moves perpendicular to the waterlevel altitude contours in the horizontal direction assuming the aquifer is homogeneous and isotropic. Where the water-level altitudes in the shallow part of an aquifer are above those in the deep part, water tends to move downward. Where the water-level altitudes are higher in the deep part of the aquifer than the shallow part, the water tends to move upward. Where a part of an aquifer is confined or semiconfined, the waterlevel altitude in the deep part may differ substantially from and be higher than the water table in the shallow part of the aquifer.

As in the previously published water-level altitude maps for predevelopment and 1993 (Hansen and others, 2013), efforts were made to include only static water levels and wells from a single vertical (shallow or deep) part of the Equus Beds aquifer.

Table 2. Precipitation stations in and near the study area, south-central Kansas.

[WB, Weather Bureau; W, west; SW, southwest; E, east; --, not applicable]

\begin{tabular}{|c|c|c|c|c|}
\hline Precipitation station name & Period of data used & County & $\begin{array}{l}\text { Cooperative station } \\
\text { identifier }\end{array}$ & $\begin{array}{c}\text { Weather Bureau-Army-Navy (WBAN) } \\
\text { station identifer }\end{array}$ \\
\hline Wichita WB Airport & 1948 to 1954 & Sedgwick & 148828 & 13998 \\
\hline $\begin{array}{l}\text { Wichita Municipal Airport and } \\
\text { Wichita Mid-Continent Airport }\end{array}$ & 1954 to 2014 & Sedgwick & 148830 & 03928 \\
\hline Sedgwick and Sedgwick $1 \mathrm{~W}$ & 1938 to 2003 & Harvey & 147313 & -- \\
\hline Halstead 3 SW & 2003 to 2013 & Harvey & 143366 & -- \\
\hline Bentley 2 E & 2013 to 2014 & Sedgwick & 140750 & -- \\
\hline Newton $3 \mathrm{E}$ and Newton $2 \mathrm{SW}$ & 1938 to August 2014 & Harvey & 145744 & -- \\
\hline Mount Hope & 1938 to 2014 & Sedgwick & 145539 & -- \\
\hline Hutchinson Municipal Airport & 1948 to 1959 & Reno & 143926 & 13986 \\
\hline Hutchinson $10 \mathrm{SW}$ & 1959 to 2014 & Reno & 143930 & -- \\
\hline
\end{tabular}




\section{Winter 2012}

Water-level altitude maps of the shallow and deep parts of the Equus Beds aquifer in winter 2012 (figs. 4 and 5) indicated that flow in both parts of the Equus Beds aquifer continued to be generally from west to east as reported in the past (Hansen and others, 2013). In the shallow part of the aquifer, water-level altitudes ranged from a high of about $1,470 \mathrm{ft}$ in the northwest part of the study area to a low of about $1,330 \mathrm{ft}$ in the southeast part of the study area (fig. 4). Generally, the depth to water below land surface in the shallow part of the Equus Beds aquifer was about 5 to $20 \mathrm{ft}$ in the northwest part of the study area; about 10 to $15 \mathrm{ft}$ near Burrton, Kans.; about 10 to $40 \mathrm{ft}$ in the CENWWF; and about 15 to $20 \mathrm{ft}$ in the southeast part of the study area (U.S. Geological Survey, 2014). The area of closed contours in the northwest part of the study area in the shallow part of the Equus Beds aquifer indicates an area of recharge (fig. 4). In the deep part of the Equus Beds aquifer, water-level altitudes ranged from a high of about $1,440 \mathrm{ft}$ on the west edge of the study area to a low of about $1,330 \mathrm{ft}$ in the southwest corner of the study area (fig. 5). The large differences (as much as $50 \mathrm{ft}$ ) of the water-level altitudes between the shallow and deep parts of the Equus Beds aquifer in the northwest part of the study area are indicative of the semiconfined to confined conditions in the deep part of the Equus Beds aquifer in this area. Because the previously published January 2011 water-level altitude maps of the shallow and deep part of the Equus Beds aquifer (Hansen, 2011) included stressed water-level altitudes, they were not considered appropriate for comparison with the static winter 2012 water-level altitude maps.

\section{Winter 2013}

Groundwater in the shallow and deep parts of the Equus Beds aquifer continued to flow predominately from west to east in most of the study area in winter 2013 (figs. 6 and 7). Water-level altitudes in the shallow part of the Equus Beds aquifer in winter 2013 ranged from about 1,465 ft in the northwest part of the study area to about $1,330 \mathrm{ft}$ in the southeast part of the study area (fig. 6). Generally, the depth to water below land surface in the shallow part of the Equus Beds aquifer was about 5 to $25 \mathrm{ft}$ in the northwest part of the study area; about 10 to $20 \mathrm{ft}$ near Burrton, Kans.; about 10 to $45 \mathrm{ft}$ in the CENWWF; and about 15 to $20 \mathrm{ft}$ in the southeast part of the study area (U.S. Geological Survey, 2014). Water-level altitudes in winter 2013 in the deep part of the Equus Beds aquifer ranged from about 1,440 $\mathrm{ft}$ on the west edge of the study area to about $1,330 \mathrm{ft}$ in the southeast part of the study area (fig. 7). No large changes in contour patterns were seen from winter 2012 to winter 2013 in the shallow or deep parts of the Equus Beds aquifer (compare figs. 4 and 5 to figs. 6 and 7). Comparison of the location of the contours, particularly along the Little Arkansas River and in the northwest part of the study area, indicate water levels in the shallow part of the
Equus Beds aquifer were lower in winter 2013 than in winter 2012 probably from the effects of drought conditions in 2011 and 2012. Groundwater use in the study area decreased from about 68,900 acre-ft in 2011 to about 63,300 acre-ft in 2012 (Kansas Department of Agriculture and Kansas Geological Survey, 2014).

\section{Winter 2014}

Water-level-altitude contours in figures 8 and 9 show that groundwater flow in the shallow and deep parts of the Equus Beds aquifer in winter 2014 continued to be generally from west to east with an area of recharge in the shallow part of the Equus Beds aquifer in the northwest part of the study area. Water-level altitudes in the shallow part of the Equus Beds aquifer ranged from a high of about $1,470 \mathrm{ft}$ in the northwest part of the study area to a low of about $1,330 \mathrm{ft}$ in the southeast part of the study area in winter 2014 (fig. 8). Generally, the depth to water below land surface in the shallow part of the Equus Beds aquifer was less than about 5 to $25 \mathrm{ft}$ in the northwest part of the study area; about 10 to $15 \mathrm{ft}$ near Burrton, Kans.; about 10 to $40 \mathrm{ft}$ in the CENWWF; and about 10 to $15 \mathrm{ft}$ in the southeast part of the study area (U.S. Geological Survey, 2014). In the deep part of the Equus Beds aquifer, water-level altitudes ranged from a high of about $1,440 \mathrm{ft}$ on the west edge of the study area to a low of about $1,330 \mathrm{ft}$ in the southeast part of the study area (fig. 9). The increase in waterlevel altitude in the shallow part of the Equus Beds aquifer in the northwest part of the study area and along the Little Arkansas River indicate a partial recovery of water levels mostly because of increased precipitation in 2013 (fig. 2A).

\section{Summer 2012}

A statistical examination of water levels in the winter 2012, summer 2012, winter 2013, and summer 2013 periods indicate that the largest number of low water levels in the monitoring wells in the study area occurred during the summer 2012 period. The water-level-altitude maps of the shallow and deep parts of the Equus Beds aquifer in summer 2012 (figs. 10 and 11) illustrate these low water-level conditions. The water-level altitudes in summer 2012 represent stressed, not static, conditions because hydrographs for most of the wells indicated lowered water levels associated with pumping of groundwater from wells in the surrounding area. Most wells used for the summer 2012 maps are monitoring wells located some distance from pumping wells, and efforts were made to remove from the analysis the wells most affected by pumping. Consequently, these water-level altitudes still reflect the general condition in the Equus Beds aquifer at the time of measurement.

Water-level altitudes in the shallow part of the Equus Beds aquifer in summer 2012 ranged from a high of about $1,465 \mathrm{ft}$ in the northwest part of the study area to a low of about 1,330 ft in the southeast part of the study area (fig. 10). 


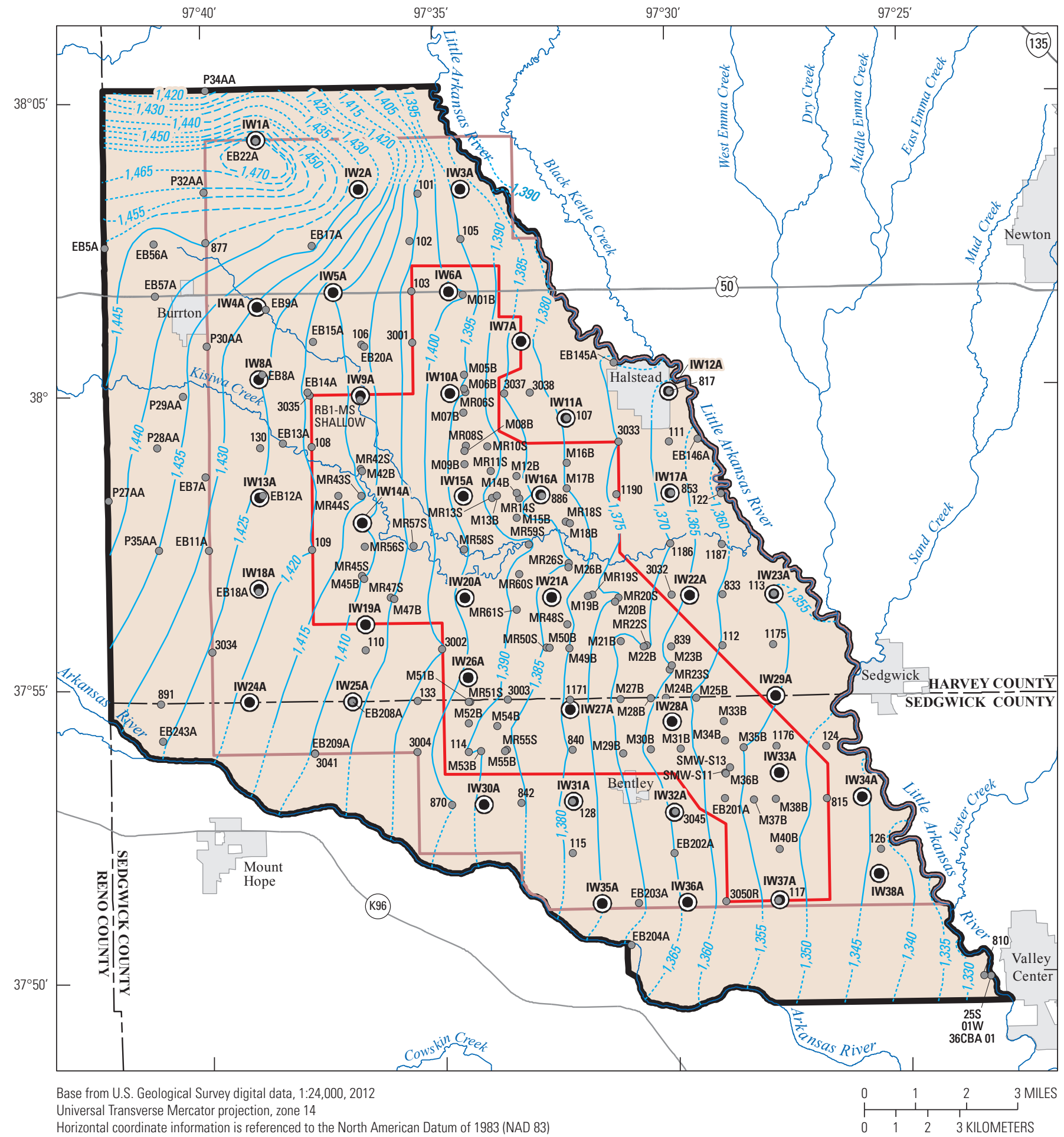

EXPLANATION
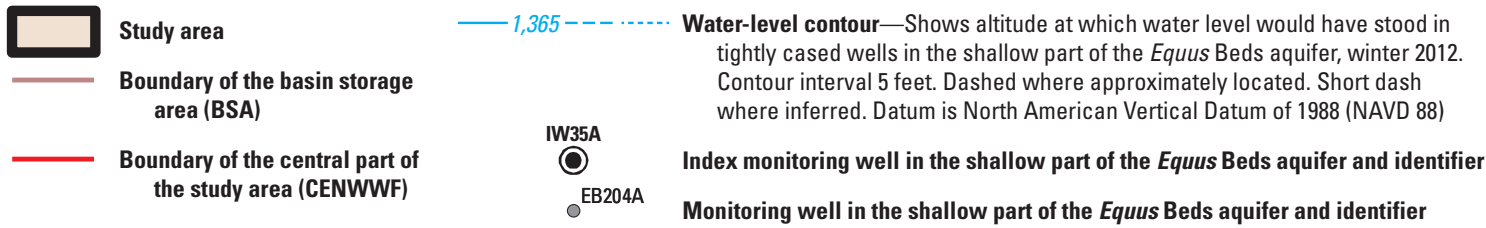

Figure 4. Static water-level altitudes in the shallow part of the Equus Beds aquifer, winter 2012. 


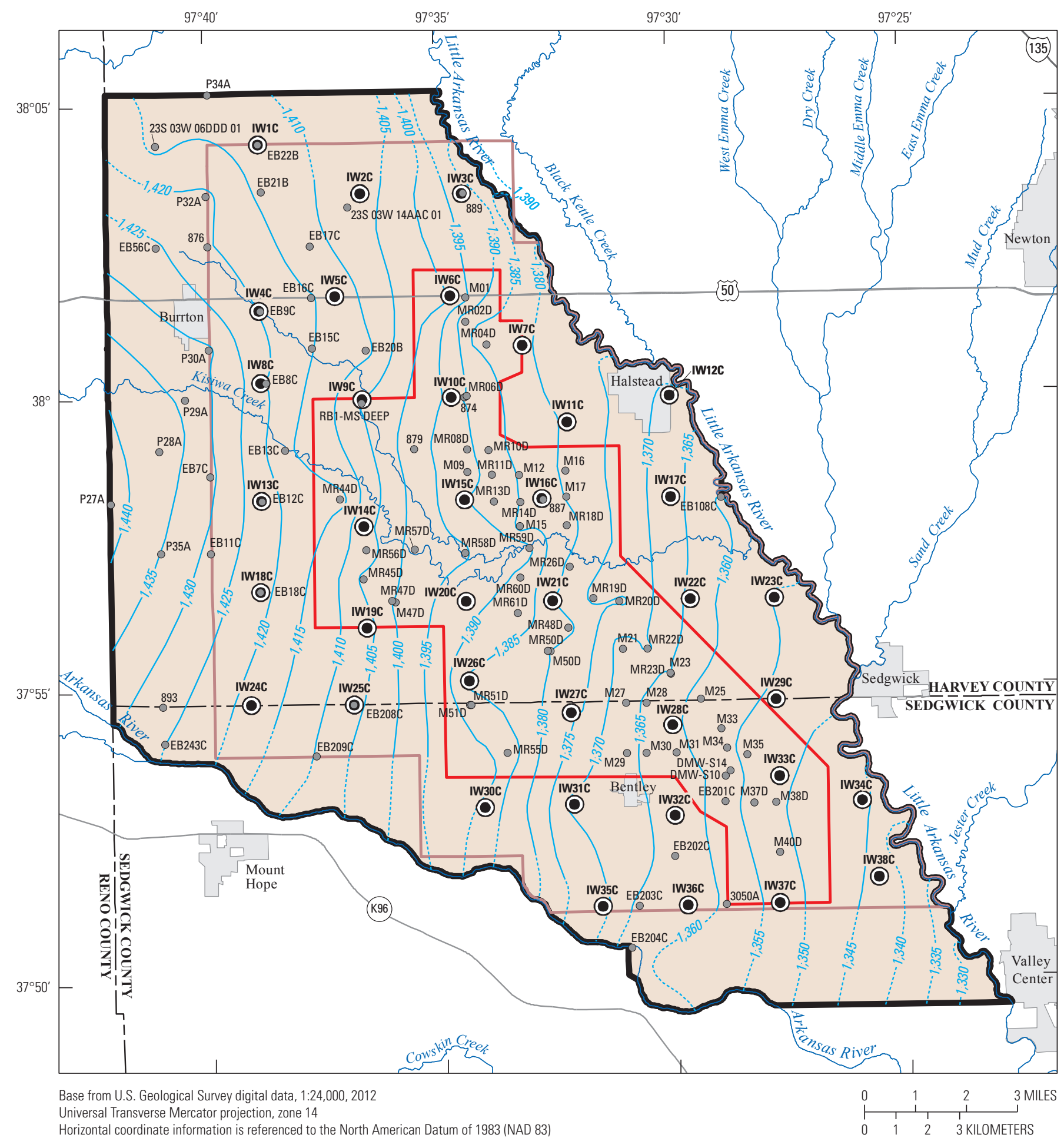

EXPLANATION

Study area
Boundary of the basin storage
area (BSA)
Boundary of the central part of
the study area (CENWWF)

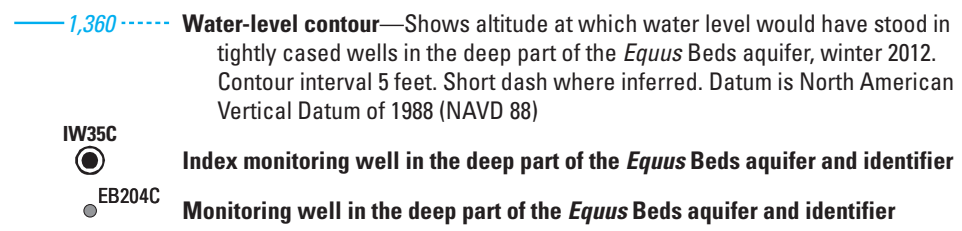

Figure 5. Static water-level altitudes in the deep part of the Equus Beds aquifer, winter 2012. 


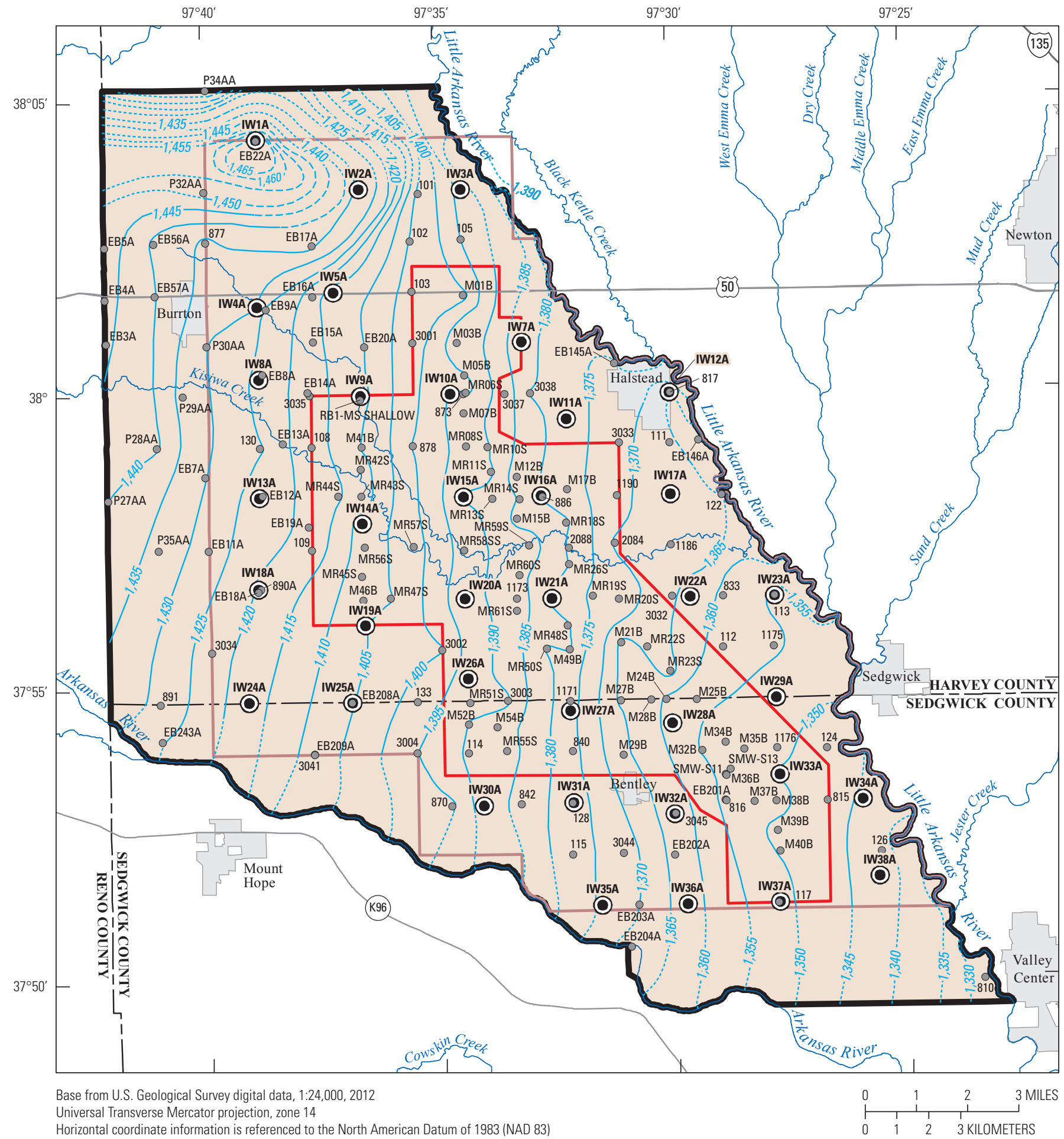

EXPLANATION
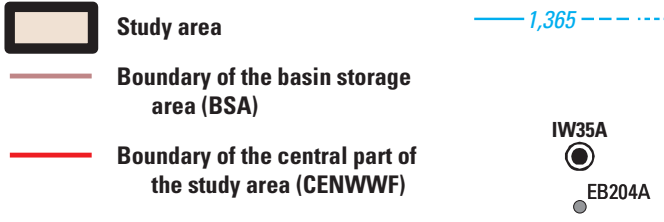

Water-level contour-Shows altitude at which water level would have stood in tightly cased wells in the shallow part of the Equus Beds aquifer, winter 2013 Contour interval 5 feet. Dashed where approximately located. Short dash where inferred. Datum is North American Vertical Datum of 1988 (NAVD 88) the study area (CENWWF)

Index monitoring well in the shallow part of the Equus Beds aquifer and identifier Monitoring well in the shallow part of the Equus Beds aquifer and identifier

Figure 6. Static water-level altitudes in the shallow part of the Equus Beds aquifer, winter 2013. 


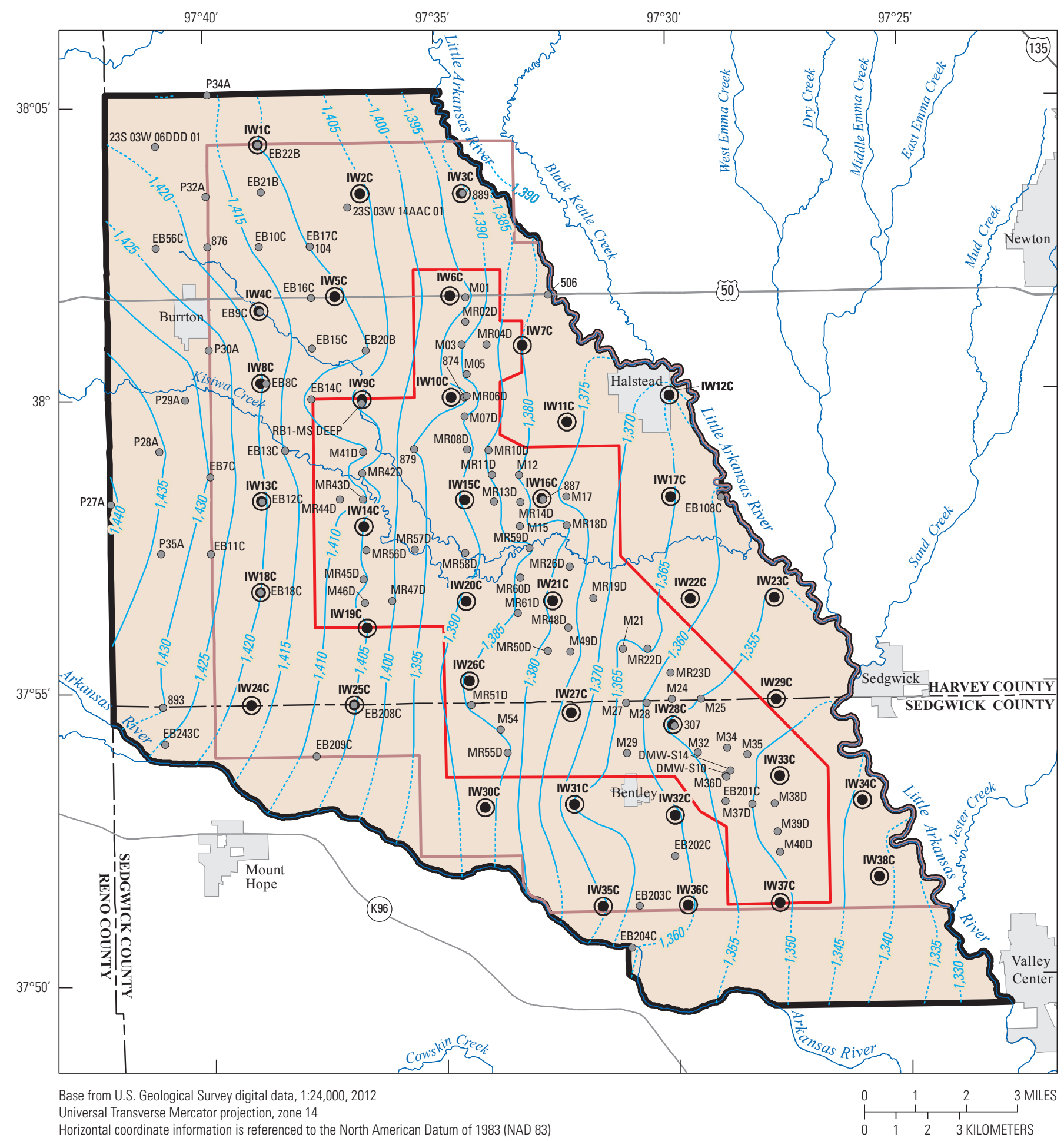

EXPLANATION
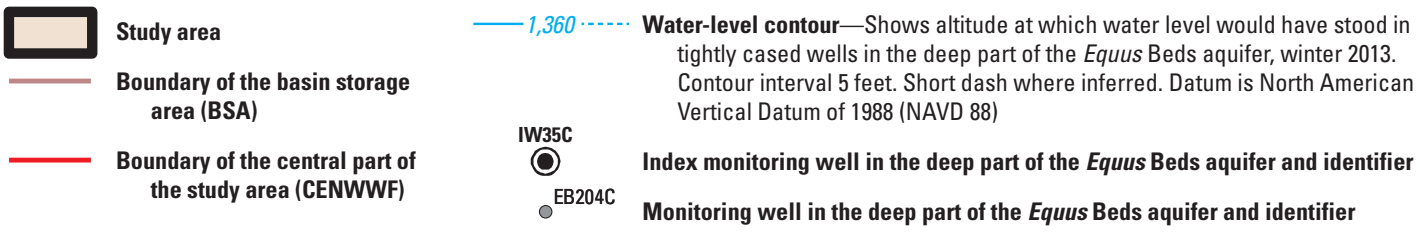

Figure 7. Static water-level altitudes in the deep part of the Equus Beds aquifer, winter 2013. 


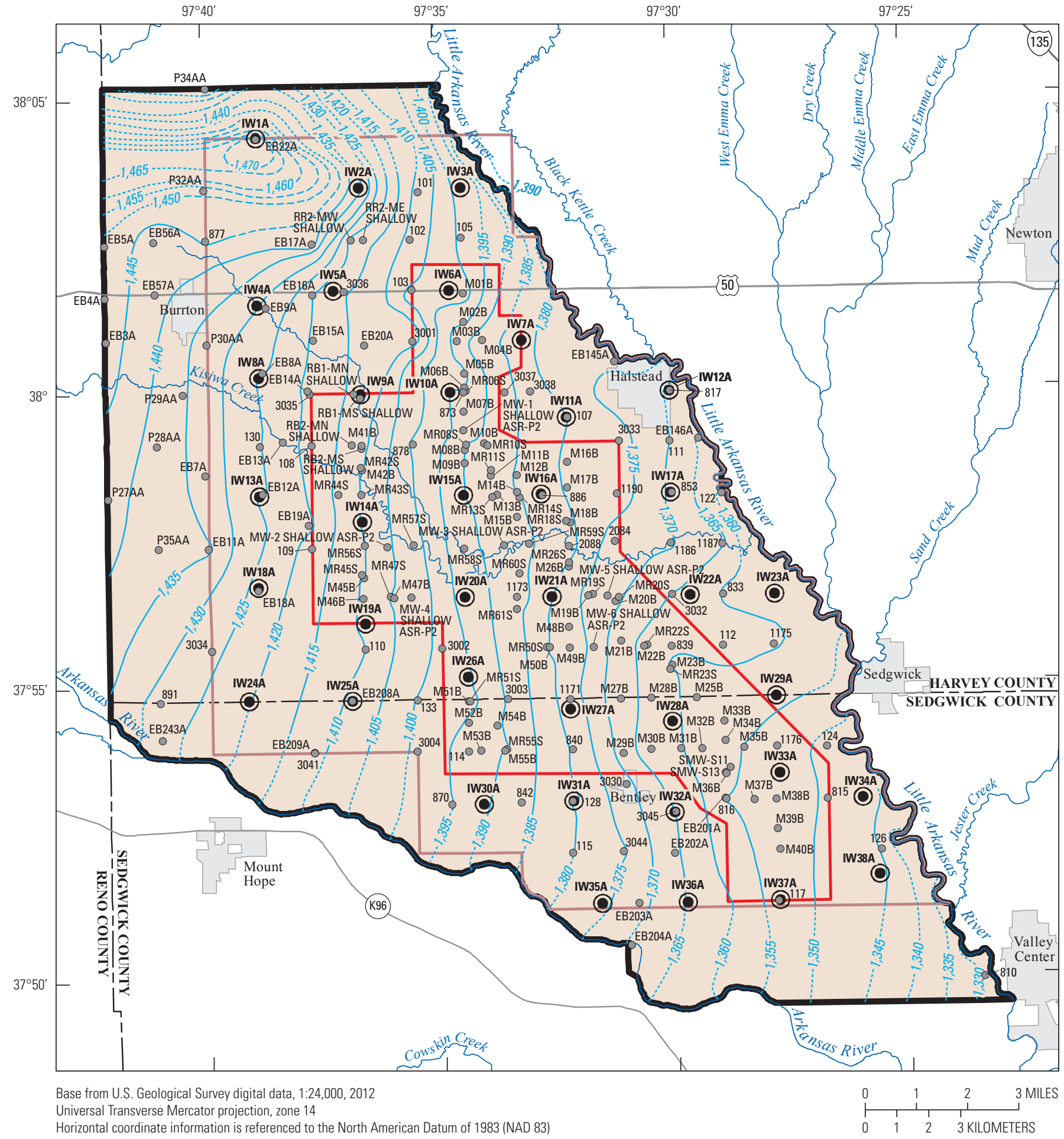

EXPLANATION
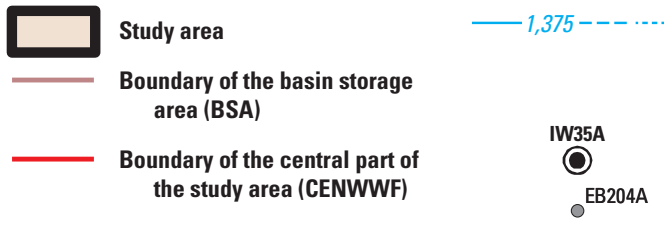

Water-level contour-Shows altitude at which water level would have stood in tightly cased wells in the shallow part of the Equus Beds aquifer, winter 2014. Contour interval 5 feet. Dashed where approximately located. Short dash where inferred. Datum is North American Vertical Datum of 1988 (NAVD 88)

Index monitoring well in the shallow part of the Equus Beds aquifer and identifier Monitoring well in the shallow part of the Equus Beds aquifer and identifier

Figure 8. Static water-level altitudes in the shallow part of the Equus Beds aquifer, winter 2014. 


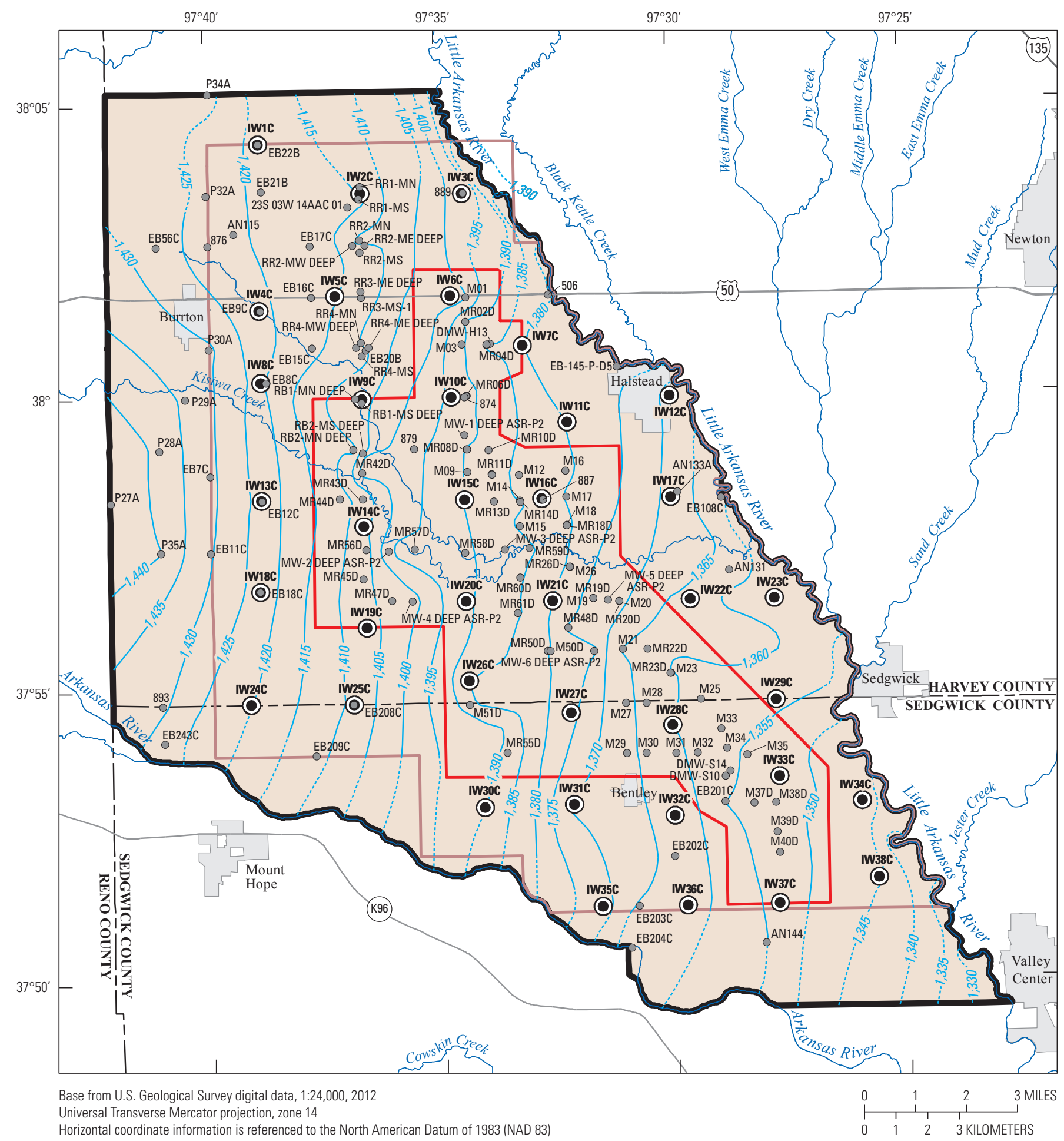

EXPLANATION

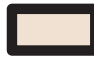

Study area

Boundary of the basin storage area (BSA)

Boundary of the central part of the study area (CENWWF)

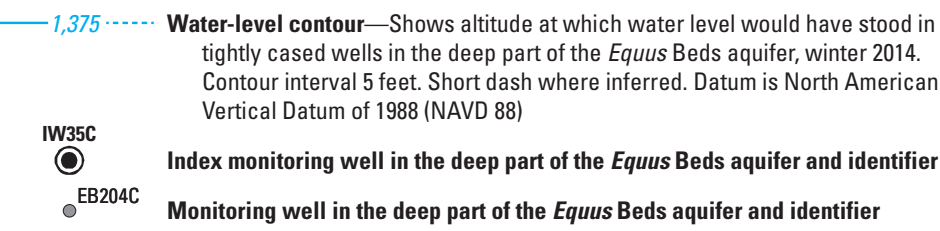
Contour interval 5 feet. Short dash where inferred. Datum is North American dex monitoring well in the deep part of the Equus Beds aquifer and identifier ${ }^{\mathrm{EB} 204 \mathrm{C}}$ Monitoring well in the deep part of the Equus Beds aquifer and identifier

Figure 9. Static water-level altitudes in the deep part of the Equus Beds aquifer, winter 2014. 
Generally, the depth to water below land surface in the shallow part of the Equus Beds aquifer was less than about 5 to $20 \mathrm{ft}$ in the northwest part of the study area; about 10 to $15 \mathrm{ft}$ near Burrton, Kans.; about 10 to $55 \mathrm{ft}$ in the CENWWF; and about 10 to $15 \mathrm{ft}$ in the southeast part of the study area (U.S. Geological Survey, 2014). In the deep part of the Equus Beds aquifer in summer 2012, water-level altitudes ranged from a high of about $1,440 \mathrm{ft}$ on the west edge of the study area to a low of about $1,330 \mathrm{ft}$ in the southeast part of the study area (fig. 11). Examination of figures 10 and 11 show the same general pattern of groundwater flow in summer 2012 as in winter 2012, 2013, and 2014; flow was from west to east in the shallow and deep parts of the Equus Beds aquifer with a large area of recharge in the northwest part of the study area in the shallow part of the Equus Beds aquifer.

The most obvious difference in the water-level altitudes in summer 2012 compared with winter 2012, 2013, and 2014 is the area west and northwest of Halstead, Kans., where low water levels in summer 2012 extend to the northwest from near wells IW11A and IW11C to near IW3A and IW3C (figs. 10 and 11). In this area, the direction of flow was from east to west in summer 2012 as water that formerly discharged to the Little Arkansas River was pumped out of the Equus Beds aquifer by wells in the area west and northwest of Halstead, Kans. (figs. 10 and 11). By winter 2013 the flow direction returned to an east to west direction in the area from IW11 A and IW11C to IW3A and IW3C (compare figs. 10 and 11 to 6 and 7). Much of the rise in water levels in the study area from summer 2012 to winter 2013 probably was because of the decrease in irrigation pumpage associated with the end of the growing season. Recharge from precipitation probably was a smaller factor than normal in the rise in water levels in

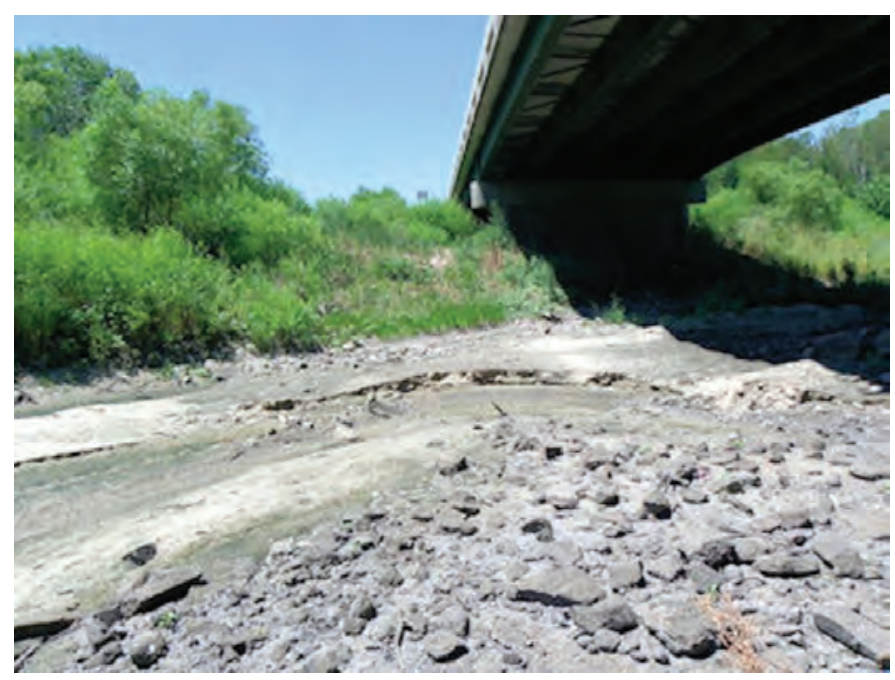

No flow in the Little Arkansas River at Highway 50 near Halstead, Kansas, July 27, 2012. Photograph by Barbara J. Dague, U.S. Geological Survey. the study area from summer 2012 to winter 2013. Average precipitation in the study area during September through December 2012 was only 4.25 in. or about 51 percent of the study area's long-term (1938 through 2013) average precipitation for September through December of 8.26 in. (National Oceanic and Atmospheric Administration, 2014a). Therefore, it is possible that a substantial part of the rise in water levels from summer 2012 to winter 2013 may be because of the westward inflow of groundwater from outside the study area.

\section{Water-Level and Storage-Volume Changes in the Equus Beds Aquifer}

By comparing water-level altitude changes between two time periods, the vertical and horizontal areas affected by water-level changes can be determined. The changes also can be used to estimate the storage-volume of the aquifer within which water-level changes have occurred. The average water-level changes in the three study areas since predevelopment in winter 2012, summer 2012, winter 2013, and winter 2014 for the shallow part of the Equus Beds aquifer; and since 1993 for winter 2012, summer 2012, winter 2013, and winter 2014 for the shallow and deep parts of the Equus Beds aquifer are shown in table 3 . These changes were determined using three methods (previously described in the Water-Level Change subsection of the Methods section). Average waterlevel changes since predevelopment were not determined for the deep part of the Equus Beds aquifer because of the low data density (Hansen and others, 2013). The largest average water-level changes since predevelopment for winter 2012, summer 2012, winter 2012, and winter 2014 occurred in summer 2012 in the shallow part of the Equus Beds aquifer in the entire study area and the BSA for all three methods (table 3). However, summer 2012 is not the obvious low since predevelopment for the 2012 to 2014 period in the CENWWF. Smaller average water-level changes since 1993 indicate water levels were closer to the record to near-record lows of 1993. The smallest average water level changes since 1993 in winter 2012, summer 2012, winter 2013, and winter 2014 generally occurred in summer 2012 in the shallow and deep parts of the Equus Beds aquifer in the study area and in the BSA, but only in the deep part of the Equus Beds aquifer in the CENWWF (table 3 and fig. 12). The average increase in water levels since 1993 in winter 2012, summer 2012, winter 2013, and winter 2014 ranged from about 6 to $12 \mathrm{ft}$ in the CENWWF compared to only about 3 to $8 \mathrm{ft}$ in the study area (table 3 ). The larger average water-level increases since 1993 in the CENWWF compared with those in the study area and BSA indicate that the CENWWF had more post-1993 water-level recovery than did the rest of the study area (fig. 12). 


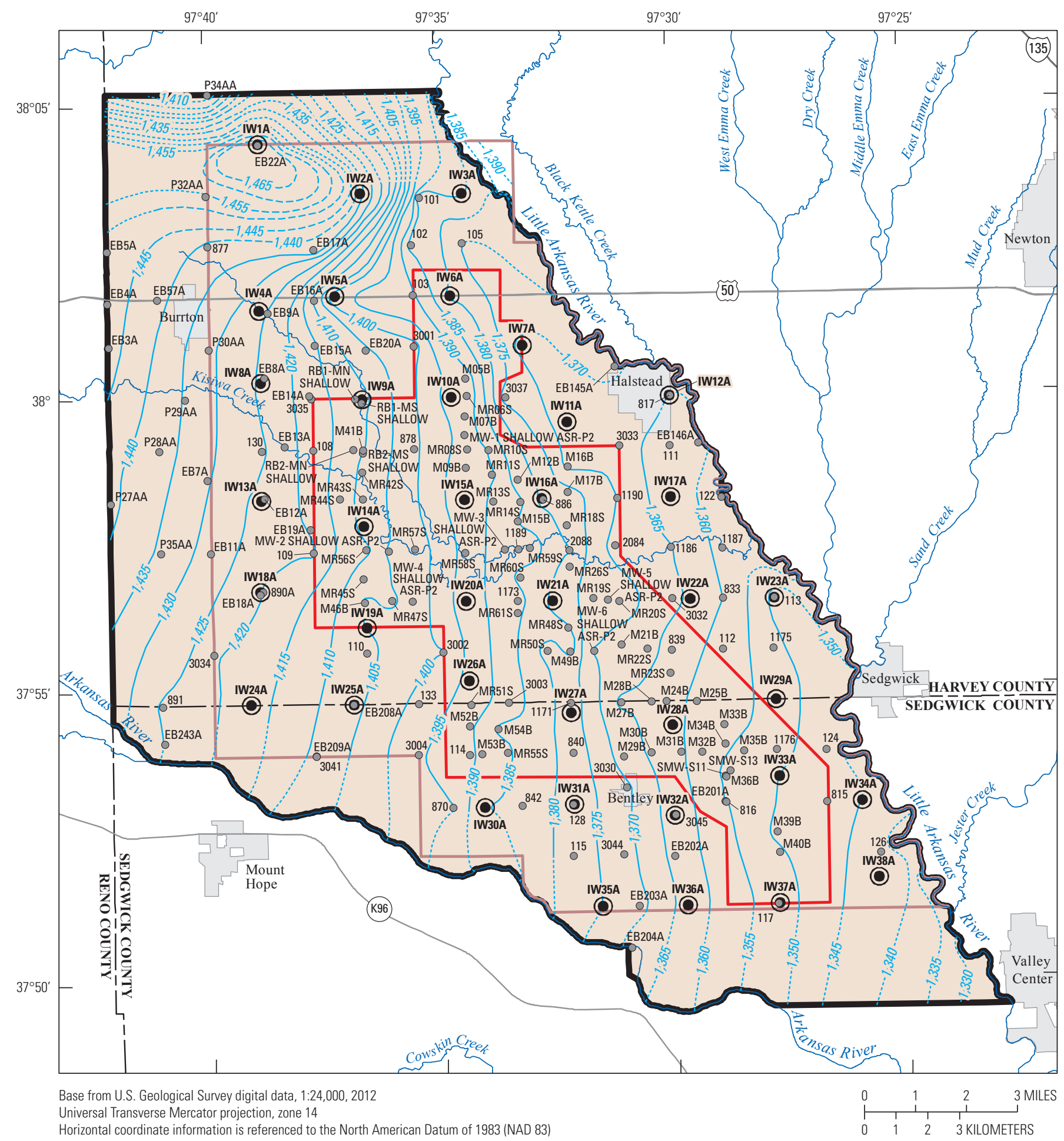

EXPLANATION
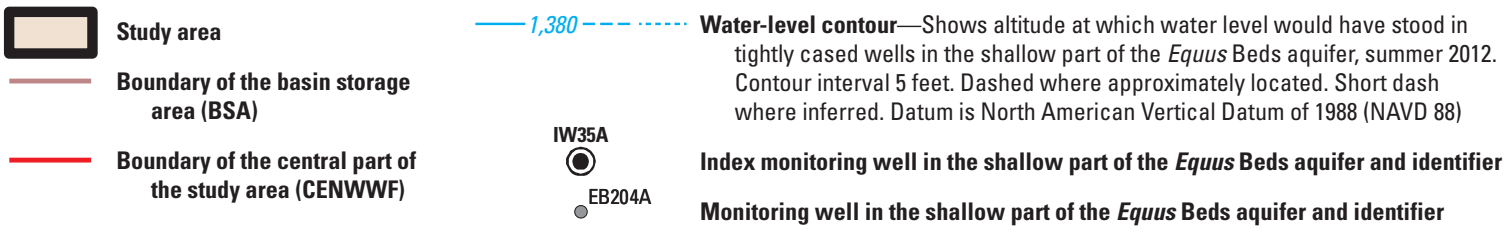

Figure 10. Water-level altitudes in the shallow part of the Equus Beds aquifer, summer 2012. 


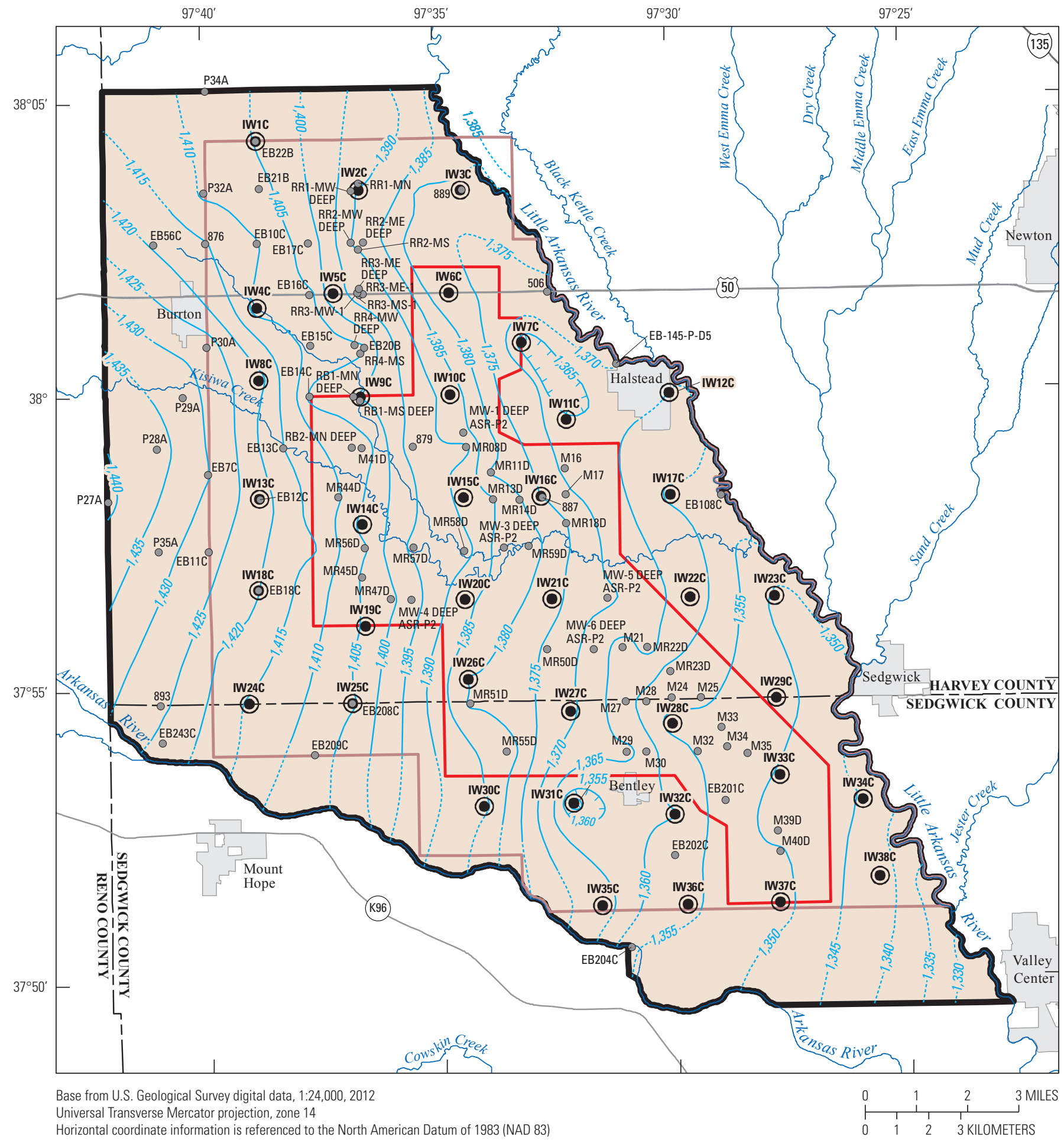

EXPLANATION
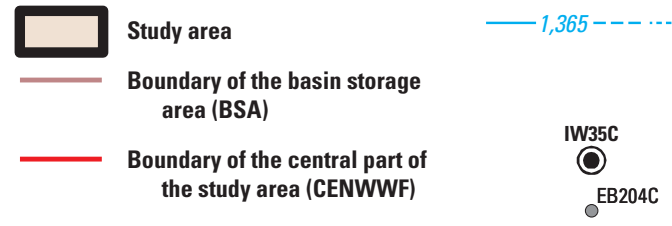

Water-level contour-Shows altitude at which water level would have stood in tightly cased wells in the deep part of the Equus Beds aquifer, summer 2012 Contour interval 5 feet. Short dash where inferred. Hachures indicate depression. Datum is North American Vertical Datum of 1988 (NAVD 88)

EB204C

Index monitoring well in the deep part of the Equus Beds aquifer and identifier

Monitoring well in the deep part of the Equus Beds aquifer and identifier

Figure 11. Water-level altitudes in the deep part of the Equus Beds aquifer, summer 2012. 
Table 3. Average water-level changes, storage-volume changes, and total aquifer storage volume in the Equus Beds aquifer near Wichita, south-central Kansas, predevelopment to winter 2014.

[Predevelopment is defined as before substantial pumpage began in the area. --, not applicable; $<$, less than]

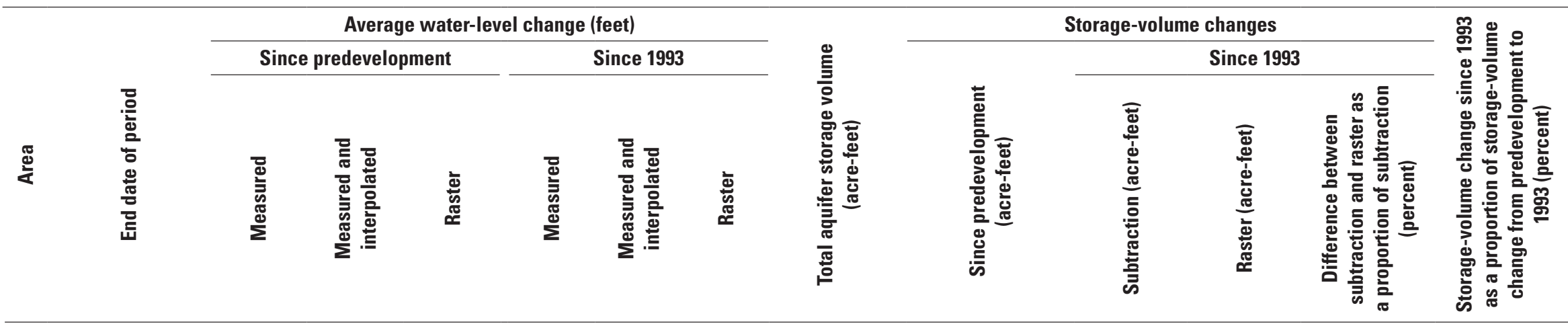

Shallow part of the Equus Beds aquifer

Study area

Predevelopment

1993

Winter 2012

Summer 2012

Winter 2013

$-9.16$

$-9.34$

$-7.31$

$-10.70$

$-11.61$

$-10.07$

$-9.71$

$-9.52$

$-8.92$

3.11

Winter 2014

$-6.82$

7.80

$\begin{array}{ccc}-- & -- & 13,192,000 \\ -- & -- & --\end{array}$

Basin storage area

Predevelopment

1993

$-$

Winter 2012

--

Summer 2012

$$
-10.20
$$

${ }^{1}-17.33$

$-13.97$

Winter 2013

$-8.41$

$-$

tral part of the study area

Predevelopment

1993

$-11.72-12.46$

$-11.60$

-- 6.20

6.20

$-9.98$

3.50

3.74

$-10.68-10.35$

$-8.10$

$\begin{array}{lll}8.62 & 8.58 & 5.01\end{array}$

Winter 2012

1-31.0

Summer 2012

$-12.72$

$--$

$--$

$--$

$$
-
$$

Winter 2013

$-13.85$

$-9.53$

10.74

$-13.73$

$-14.07$

9.00

$-14.72$

$-13.57$

$-13.13$

7.95

$-12.04$

$\begin{array}{rrr}12.18 & 12.09 & 10.94\end{array}$

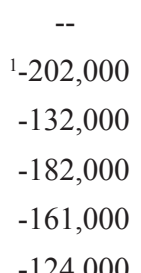

\section{--}

70,000

20,000

41,000

78,000

70,100

20,100

41,000

78,900

${ }^{12,400,000}$

--

$-$

$-$

--

${ }^{1} 1,025,000$

--

$-$

$-$

$-$
${ }^{1}-188,000$

$-113,000$

$-156,000$

$-134,000$

$-109,000$

$-120,000$

$-58,300$

$-73,700$

$-68,700$

$-63,100$

61,700

46,300

51,300

56,900

57,300

$<1$ 
Table 3. Average water-level changes, storage-volume changes, and total aquifer storage volume in the Equus Beds aquifer near Wichita, south-central Kansas, predevelopment to winter 2014.-Continued

[Predevelopment is defined as before substantial pumpage began in the area. --, not applicable; <, less than]

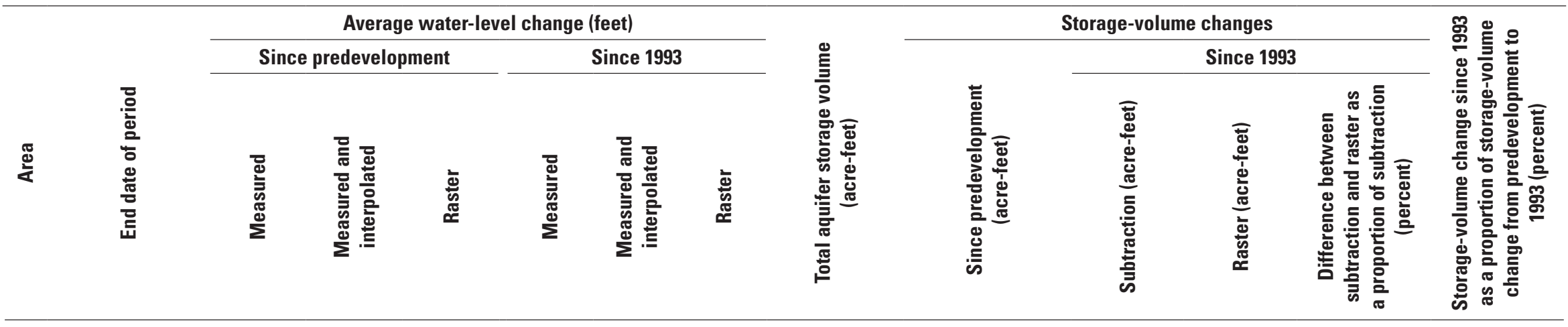

Deep part of the Equus Beds aquifer

Study area

Winter 2012

Summer 2012

Winter 2013

Winter 2014

Basin storage area

Winter 2012

Summer 2012

Winter 2013

Winter 2014

Central part of the study area

Winter 2012

Summer 2012

Winter 2013

Winter 2014

${ }^{1}$ Average water-level, storage-volume change, or total aquifer volume previously reported in Hansen and others (2013). 


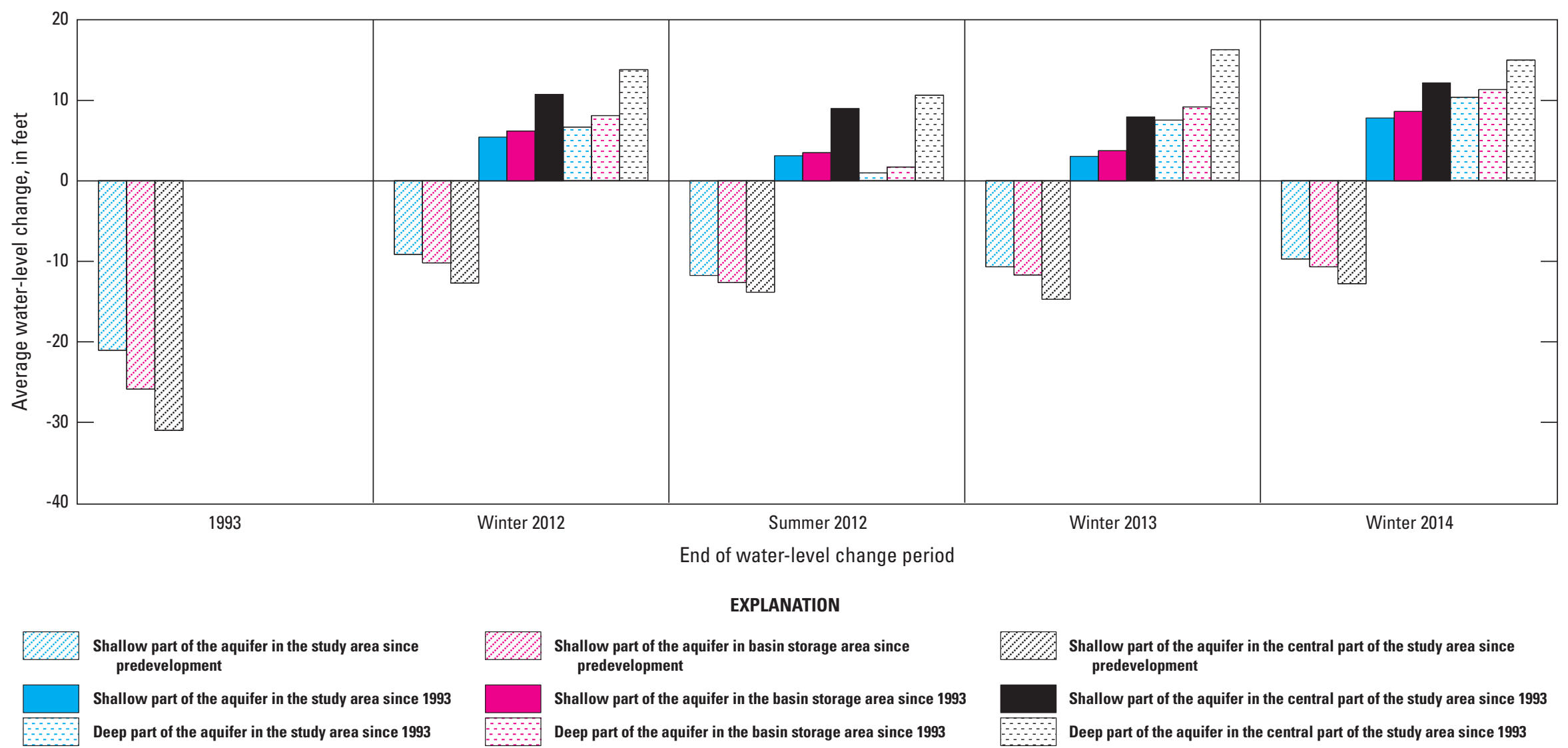

Figure 12. Average measured water-level changes in the Equus Beds aquifer in the shallow part of the aquifer since predevelopment and in the shallow and deep parts of the aquifer since 1993. 
As noted by Kelly and others (2013), most of the waterlevel and storage-volume changes occurred in the shallow part of the Equus Beds aquifer. This is because most of the water that comes out of storage is from the unconfined part of the aquifer, which is typically the shallow part of the aquifer. Where an aquifer is semiconfined to confined, water that comes out of storage is from the expansion of water and the compression of the aquifer, and not from dewatering of the aquifer (Heath, 1983). If the shallow and deep parts of the aquifer layers are unconfined, water levels in both parts will be similar, and use of specific yield to estimate the storagevolume change is appropriate. However, if the shallow part of the aquifer is unconfined and the deep part is semiconfined to confined, use of specific yield is appropriate for estimating the storage-volume change only for the shallow part; a storage coefficient must be used for the deep part. Kelly and others (2013) used a specific yield of 0.15 where the Equus Beds aquifer was unconfined and a storage coefficient of 0.0005 where it was semiconfined to confined. Use of specific yield and water-level changes in the deep part of the Equus Beds aquifer where it is semiconfined to confined will overestimate the amount of storage-volume change by a factor of about 300 . Therefore, although water-level changes in the deep part of the Equus Beds aquifer may be larger than those in the shallow part of the Equus Beds aquifer in semiconfined to confined areas, the contribution of the deep part of the Equus Beds aquifer to the total storage-volume change will be small. Kelly and others (2013) state:

Use of groundwater level changes that do not include storage changes that occur in confined or semi-confined part of the aquifer will slightly underestimate storage changes; however, use of specific yield and groundwater level changes to estimate storage change in confined or semi-confined parts of the aquifer will overestimate storage changes. Using only changes in shallow groundwater levels will provide more accurate storage changes for the measured groundwater levels method.

Thus, the use of water-level changes in the shallow part of the Equus Beds aquifer is more appropriate for determining storage-volume changes than the use of water-level changes in the deep part of the Equus Beds aquifer, which includes semiconfined to confined conditions in part of the area.

Comparison of the average water-level changes in the study area in the shallow part of the Equus Beds aquifer with those in the deep part aquifer for summer 2012 and winter 2014 (fig. 12) demonstrates how the water-level changes are greater in the deep part of the Equus Beds aquifer than in the shallow part, which, if used, could lead to the overestimation of storage-volume changes. Average water-level changes in the study area in the deep part of the Equus Beds aquifer from 1993 to summer 2012 ranged from 0.97 to $2.12 \mathrm{ft}$ less than in the shallow part of the aquifer (table 3). In contrast, from 1993 to winter 2014, average water-level changes in the study area in the deep part of the Equus Beds aquifer were 2.19 to $2.58 \mathrm{ft}$ greater than in the shallow part of the Equus Beds aquifer (table 3). Storage-volume changes since predevelopment in the shallow part of the Equus Beds aquifer in the study area, BSA, and CENWWF exhibited larger declines in summer 2012 than in winter 2012, 2013, or 2014 (fig. 13). However, these declines since 1993 were substantially less than the declines from predevelopment to 1993 (table 3 and fig. 13).

The storage-volume changes since 1993 shown in table 3 were computed by two methods. In the first method, the "since predevelopment" value for the beginning of the period was subtracted from the "since predevelopment" value for the end of the period, which is the method used in previous reports by Aucott and Myers (1998), Aucott and others (1998), Hansen (2007, 2009a, 2009b, 2011a, 2011b, 2012), and Hansen and Aucott $(2001,2004,2010)$. The second method of storagevolume changes since 1993 were computed by using the water-level-change rasters. The differences between the two methods are within 1 percent of each other (table 3 ). The continued use of subtraction of the storage-volume changes since predevelopment instead of subtraction of the waterlevel-change rasters would seem to be an acceptable and efficient method for computing storage-volume changes for periods other than since predevelopment without introducing large errors.

\section{Predevelopment to Winter 2014}

Water levels mostly declined from predevelopment to winter 2014 in the study area (fig. 14). Declines of $10 \mathrm{ft}$ or more were common in and adjacent to the CENWWF and in the northwest part of the study area. Areas with rises of less than $10 \mathrm{ft}$ were seen along the Little Arkansas River and in the west part of the study area (fig. 14). Declines of $20 \mathrm{ft}$ or more mostly occurred in areas where the city does not have production wells. This is a change from previous patterns of water-level change where the largest declines occurred within the CENWWF where Wichita has production wells (Hansen and Aucott, 2010). Annual city pumpage from the study area, almost all of which was from the CENWWF, remained less than 22,000 acre-ft for 2010 through 2013, whereas annual irrigation pumpage from the study area increased by more than 25 percent from about 32,100 acre-ft in 2010 to about 45,500 and 40,800 acre-ft in 2011 and 2012 (fig. 2B). Most of the increase in irrigation pumpage occurred outside the CENWWF; irrigation pumpage in the CENWWF accounted for only about 28 percent of the irrigation pumpage in the study area in 2010 through 2012. Irrigation pumpage in the CENWWF increased from about 9,000 acre-ft in 2010 to about 12,400 and 11,700 acre-ft in 2011 and 2012, respectively. Conversely, the increase in irrigation pumpage in the rest of the study area was much larger, increasing from about 23,100 acre-ft in 2010 to about 33,100 and 29,100 acre-ft in 2011 and 2012 (fig. 15). This indicates that increased irrigation pumpage is the likely cause of the larger declines that occurred outside the CENWWF. 


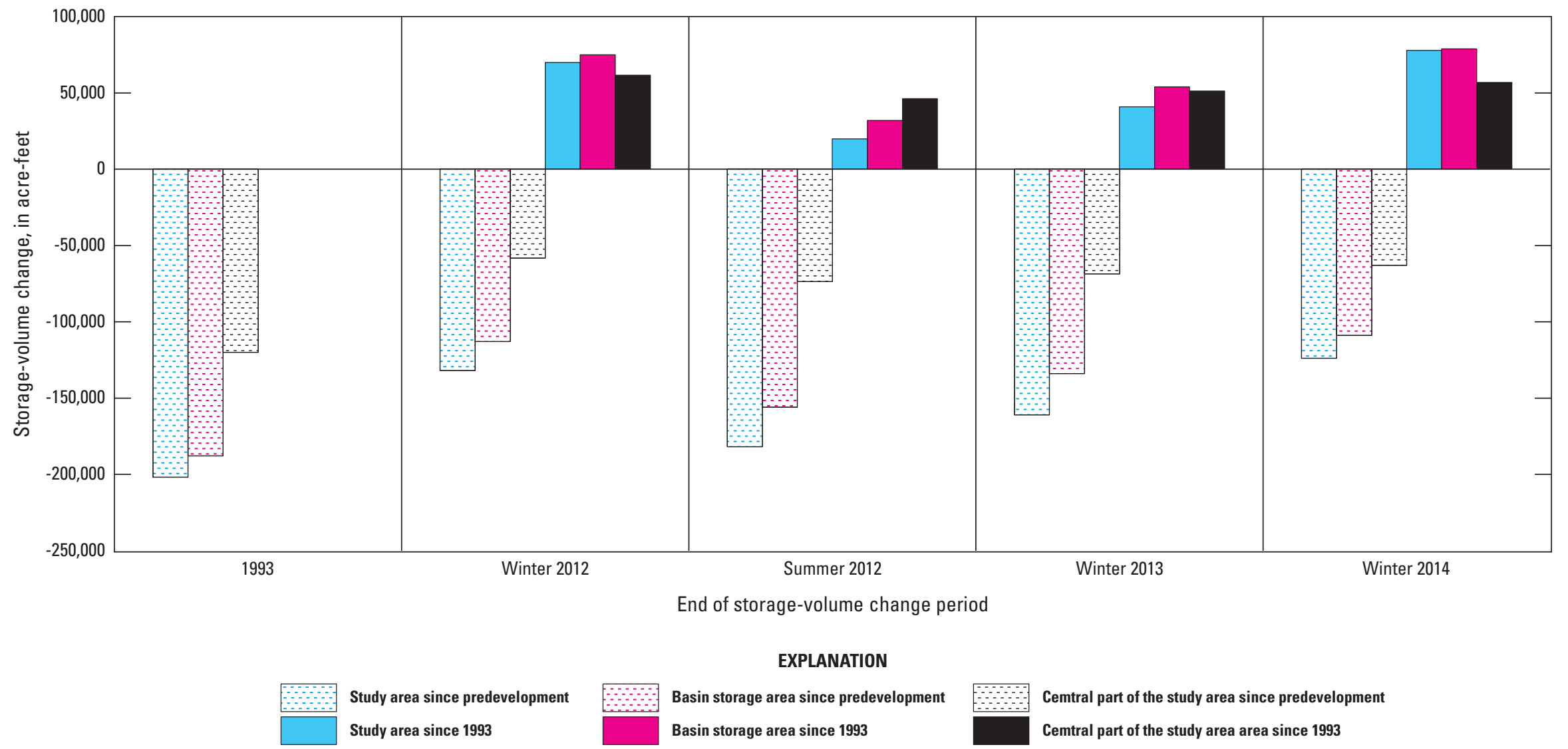

Figure 13. Storage-volume changes since predevelopment and since 1993 in the study area, the basin storage area, and the central part of the study area. 


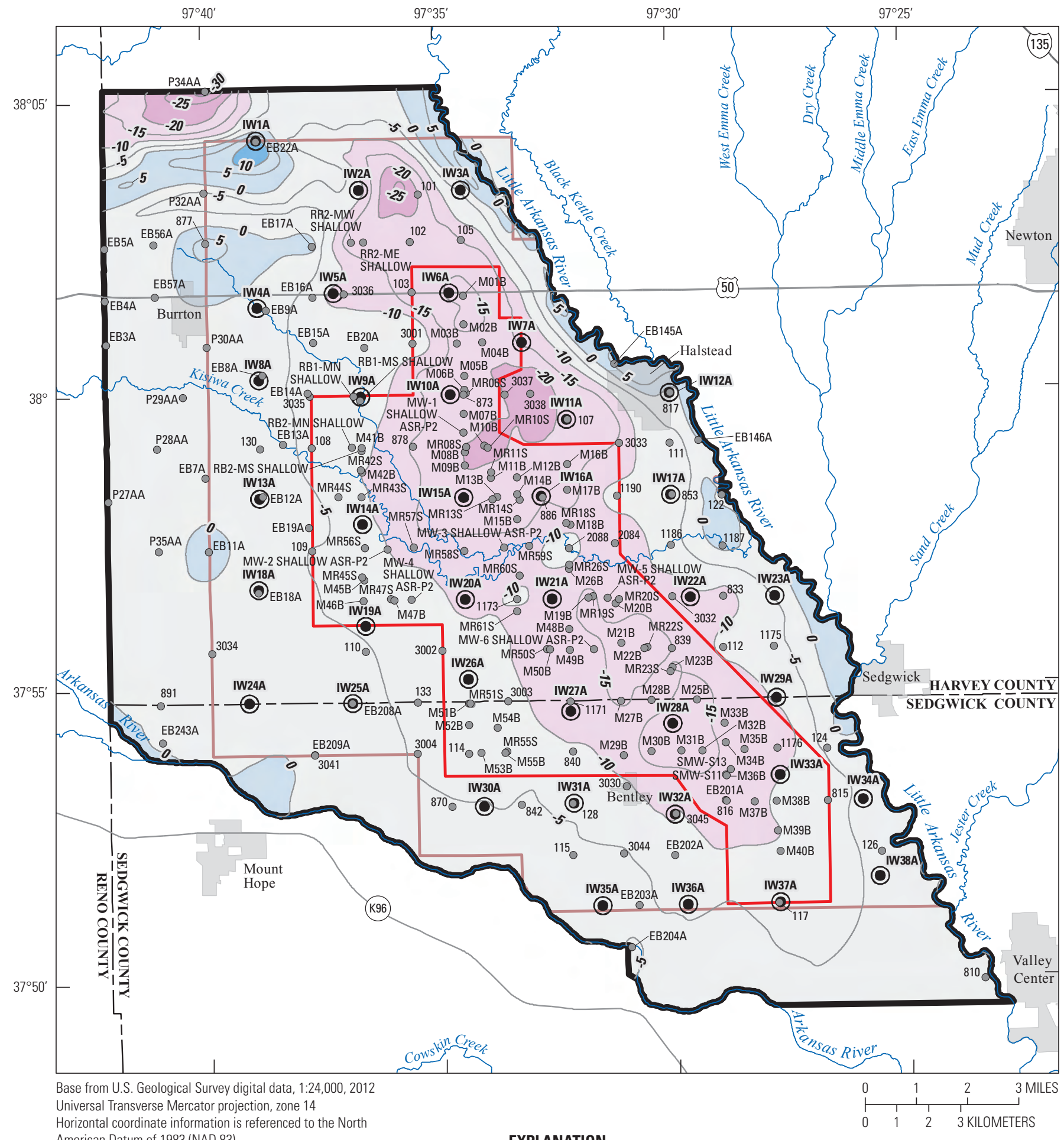

American Datum of 1983 (NAD 83)

EXPLANATION

\begin{tabular}{|c|c|}
\hline \multicolumn{2}{|c|}{$\begin{array}{l}\text { Area of water-level change in the shallow part of the } \\
\text { Equus Beds aquifer, predevelopment to winter } 2014\end{array}$} \\
\hline & Decline of 30 feet or more \\
\hline & Decline of 20 to less than 30 feet \\
\hline & Decline of 10 to less than 20 feet \\
\hline & Decline of zero to less than 10 feet \\
\hline & Rise of zero to 10 feet \\
\hline & Rise of greater than 10 to 20 feet \\
\hline
\end{tabular}

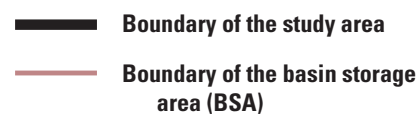

Boundary of the central part of the study area (CENWWF)

\section{-5 - Line of equal water-level change in the shallow part of the Equus Beds aquifer, predevelopment to winter 2014-Contour interval 5 feet}

( ) Index monitoring well in the shallow part of the Equus Beds aquifer and identifier

EB204A
Monitoring well in the shallow part of the Equus Beds aquifer and identifier

Figure 14. Static water-level changes in the shallow part of the Equus Beds aquifer, predevelopment to winter 2014. 


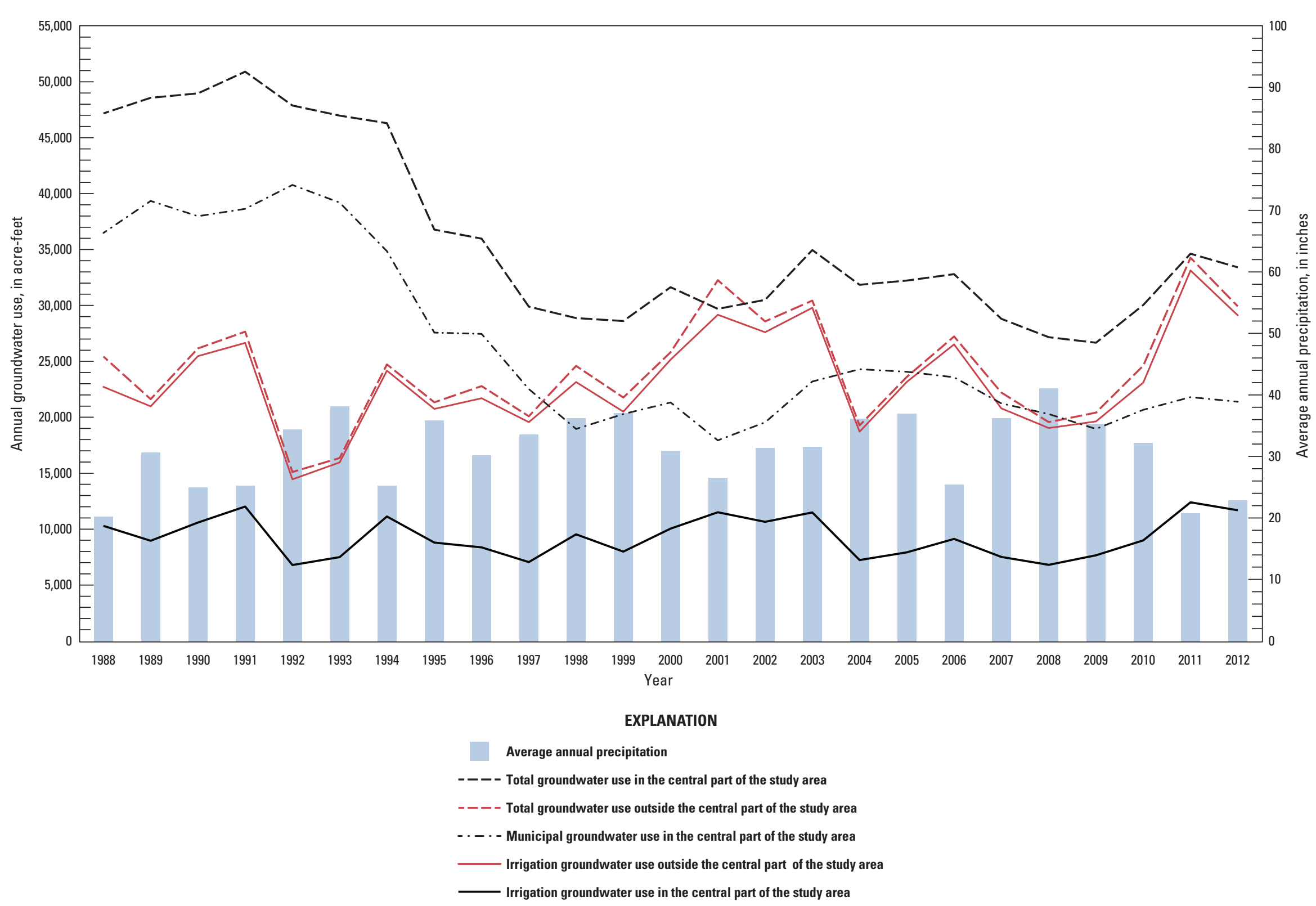

Figure 15. Annual groundwater use in the central part of the study area and in the rest of the study area and average annual precipitation in the study area, 1988 through 2012. [Water-use data are from Kansas Department of Agriculture and Kansas Geological Survey (2014); precipitation data are from National Oceanic and Atmospheric Administration (2014a).] 
The storage-volume in the Equus Beds aquifer in the study area from predevelopment to winter 2014 decreased by about 124,000 acre-ft or about a 4-percent loss of the estimated Equus Beds total aquifer storage volume of 3,192,000 acre-ft (table 3). The remaining 96-percent Equus Beds total aquifer storage volume in the study area was about 3,067,000 acre-ft. The storage-volume decrease in the CENWWF from predevelopment to winter 2014 accounted for about one-half (about 63,100 acre-ft) of the decrease in storage volume in the Equus Beds aquifer in the study area (table 3). This about 63,100 acre-ft storage-volume decrease in the CENWWF from predevelopment to winter 2014 was about a 6-percent loss from the 1,025,000 acre-ft estimated Equus Beds total aquifer storage in the CENWWF, or about a 2-percent loss of the estimated Equus Beds total aquifer volume in the study area (table 3 ). The remaining 94-percent Equus Beds total aquifer storage volume in the CENWWF was estimated to be about 962,000 acre-ft.

\section{Predevelopment to Summer 2012}

Water levels declined for almost the entire study area from predevelopment to summer 2012 (fig. 16). The summer 2012 water-levels are considered stressed. However, because they are based on water levels from monitoring wells, and not pumping wells, they reflect the general stressed condition of the Equus Beds aquifer at the time of measurement. A large area of declines of $10 \mathrm{ft}$ or more covered most of the CENWWF and extended beyond it almost to the Little Arkansas River from Sedgwick to the north edge of the BSA (fig. 16). The largest declines (40 ft or more) occurred in two areas of that are north of U.S. Highway 50 and completely outside the CENWWF (fig. 16). The three areas of declines of $30 \mathrm{ft}$ or more were mostly outside the CENWWF north of U.S. Highway 50 and west of Halstead, Kans. Because Wichita production wells are inside the CENWWF, these declines probably were related to the increased irrigation pumpage in the study area. Increased irrigation pumpage in 2012 probably was associated with drought conditions (fig. 15). Water-level declines in the CENWWF, although substantial, probably would have been even larger if Wichita had not continued the ILWSP strategy to preserve the Equus Beds aquifer by reducing city pumpage from the Equus Beds aquifer (City of Wichita, [2007?], 2008; Warren and others, 1995; Desilva and Ary, 2011).

Storage-volume decreased in the Equus Beds aquifer in the study area from predevelopment to summer 2012 by about 182,000 acre-ft (table 3). Less than one-half of this decrease (about 73,700 acre-ft) occurred in the CENWWF (table 3). Storage-volume decreases in the CENWWF probably would have been larger if Wichita had not continued to follow the ILWSP strategy of reduced city pumpage from the Equus Beds aquifer.

\section{3 to Winter 2014}

Water-levels rose in the shallow part of the Equus Beds aquifer from 1993 to winter 2014 in most of the study area (fig. 17). Water-level rises of $10 \mathrm{ft}$ or more covered most of the CENWWF, with an area of $20 \mathrm{ft}$ or more in rises southwest of Halstead, Kans. (fig. 17). These rises of $10 \mathrm{ft}$ or more mostly within the CENWWF probably resulted because of the Wichita ILWSP strategy adopted in 1993 to reduce the amount of water the city pumps from the Equus Beds aquifer (City of Wichita, [2007?], 2008; Warren and others, 1995; Desilva and Ary, 2011).

Annual irrigation pumpage in the study area increased from about 23,400 acre-ft in 1993 to more than about 40,800 acre-ft in 2011 and 2012 (fig. 2B). Irrigation pumpage increased in 2011 and 2012 in part because regulations were changed allowing irrigators to apply for drought-term and multiyear flex account (MYFA) permits. The drought-term permits allowed pumpage greater than the annual authorized amount in 2011 with an equivalent reduction in pumpage in 2012 (Kansas Department of Agriculture, Division of Water Resources, 2011). The MYFA permits are temporary permits to pump more water than the annual authorized quantity in any year, but restrict total pumpage during the 5 -year period (Kansas Legislative Research Department, 2012). The 2011 increase in irrigation pumpage in the study area attributed to the drought-term permits was estimated to be about 3,500 acre-ft. This was estimated by assuming an average extra 50 acre-ft of irrigation pumpage for each of the 70 drought-term permits (Tim Boese, Equus Beds Groundwater Management District Number 2, written commun., 2012). This is equivalent to about 8 percent of the about 45,500 acre-ft of irrigation pumpage in the study area in 2011. Assuming an extra 50 acre-ft of irrigation pumpage for each of the 35 MYFA permits in the study area, the increase in irrigation pumpage in 2012 attributed to MYFA permits was estimated to be about 1,750 acre-ft. This is equivalent to about 4 percent of the about 40,800 acre-ft of irrigation pumpage in the study area in 2012.

Storage-volume increased in the study area from 1993 to winter 2014 by about 78,000 acre-ft or a recovery of about 39 percent of the storage volume previously lost from predevelopment to 1993 (table 3). There was a larger percentage of increase in storage volume since 1993 for winter 2012, summer 2012, winter 2013, and winter 2014 in the CENWWF than in either the BSA or the entire study area (table 3). About 73 percent (about 56,900 acre-ft) of the increase in storage volume from 1993 to winter 2014 occurred in the CENWWF (table 3). This increase probably resulted because of Wichita's ILWSP strategy to preserve the Equus Beds aquifer by reducing the amount of city pumpage from it (City of Wichita, [2007?], 2008; Warren and others, 1995; Desilva and Ary, 2011). The city reduced its annual pumpage from the Equus Beds aquifer by about 40 percent since 1992 (fig. 2B). 


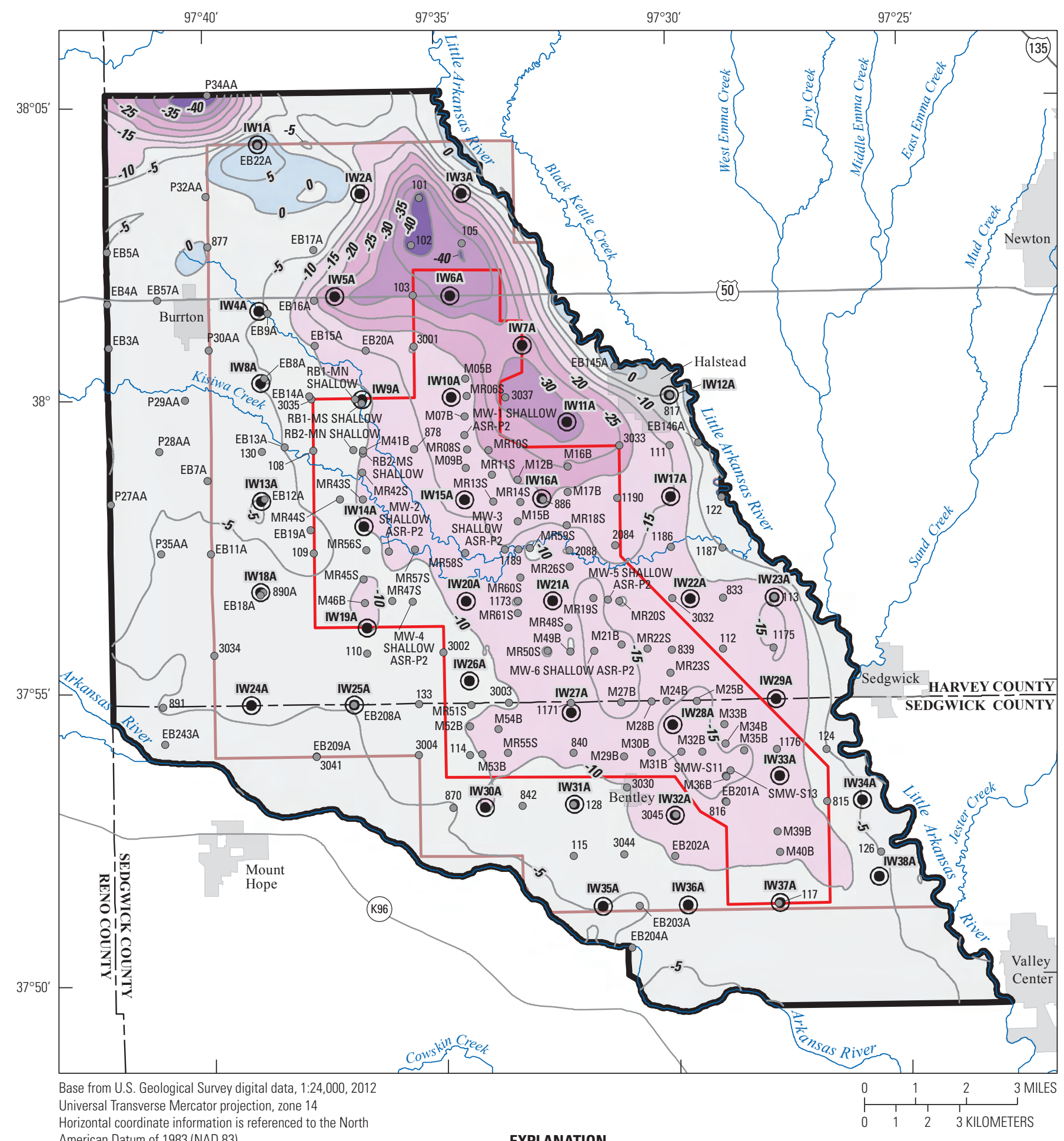

American Datum of 1983 (NAD 83)

\section{EXPLANATION}

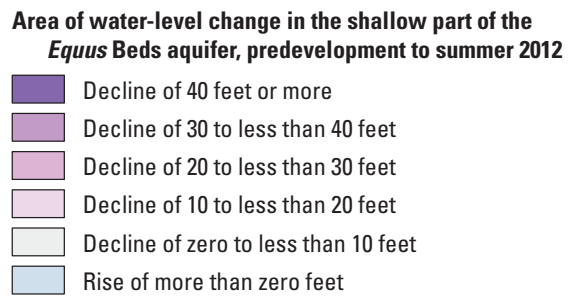

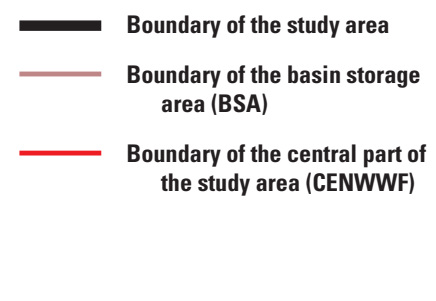

-5 - Line of equal water-level change in the shallow part of the Equus Beds aquifer, predevelopment to summer 2012 - Contour interval 5 feet

( Index monitoring well in the shallow part of the Equus Beds aquifer and identifier

EB204A Beds aquifer and identifier

Figure 16. Water-level changes in the shallow part of the Equus Beds aquifer, predevelopment to summer 2012. 


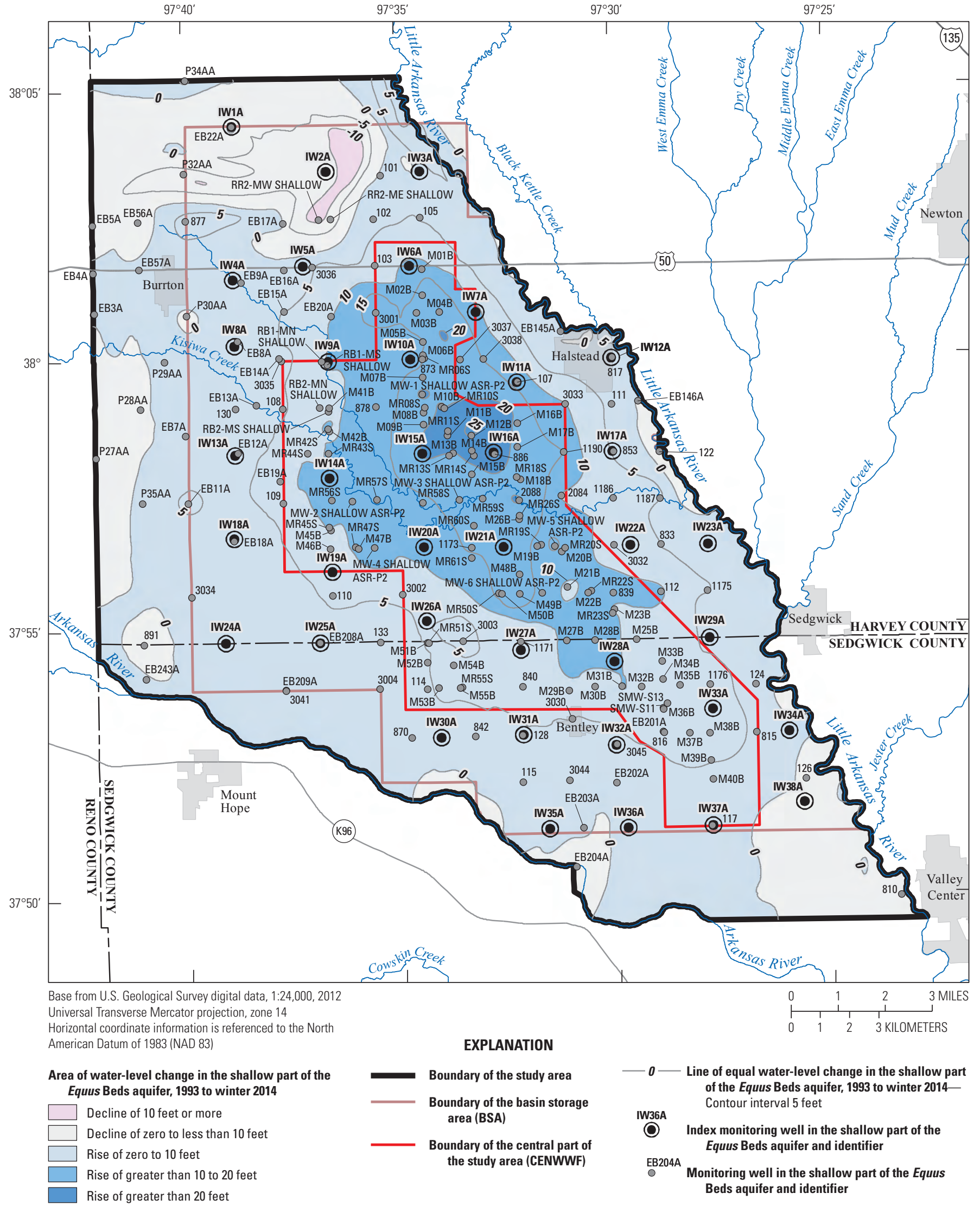

Figure 17. Static water-level changes in the shallow part of the Equus Beds aquifer, 1993 to winter 2014. 
Annual city pumpage during 1988 through 2012 decreased from a peak of about 40,000 acre-ft in 1992 to about 22,000 acre-ft in 1997 (fig. 2B). Since 1997, annual city pumpage in the CENWWF has remained less than about 24,000 acre-ft (figs. $2 B$ and 15). Annual irrigation pumpage in the CENWWF and average annual precipitation for the study area during 1988 through 2012 were variable, but do not indicate obvious trends (fig. 15). Annual irrigation pumpage in the CENWWF increased by only about 3 percent during 1988 through 2012 from the pre-1993 peak of about 12,000 acre-ft in 1991 to a peak in 2011 of about 12,400 acre-ft (fig. 15). Annual irrigation pumpage outside the CENWWF increased by about 24 percent during 1988 through 2012 from the pre-1993 peak of about 26,600 acre-ft in 1991 to a peak in 2011 of about 33,100 acre-ft (fig. 15).

\section{3 to Summer 2012}

Static water-level changes in the shallow and deep parts of the Equus Beds aquifer from 1993 to summer 2012 indicate similar patterns with water-level rises in much of the study area and water-level declines of $5 \mathrm{ft}$ or more mostly north of U.S. Highway 50 (figs. 18 and 19). These declines, because they are almost entirely outside the CENWWF where the city production wells are located, probably were because of increased irrigation pumpage associated with drought conditions during 2012 (figs. $2 A$ and $2 B$ ). Water-level rises of $10 \mathrm{ft}$ or more in the shallow and deep parts of the Equus Beds aquifer from 1993 to summer 2012 occurred mostly in the CENWWF (figs. 18 and 19). These rises likely are because of Wichita's strategy reducing city pumpage from the Equus Beds aquifer from about 60 to 40 percent of city usage (City of Wichita, [2007?] and 2008; Warren and others, 1995). The water-level changes in the deep part of the Equus Beds aquifer from 1993 to summer 2012 (fig. 19) indicate more area was affected by water-level declines than in the shallow part of the Equus Beds aquifer (fig. 18). In addition, there is a larger area of water-level rises of $20 \mathrm{ft}$ or more in the shallow part of the Equus Beds aquifer from 1993 to summer 2012 than in the deep part of the Equus Beds aquifer (figs. 18 and 19). Wichita's reduction in city pumpage in the CENWWF minimized water-level declines and contributed to the water-level rises since 1993 of as much as $25 \mathrm{ft}$ in the shallow part of the Equus Beds aquifer (fig. 18). This also contributed to average waterlevel rises since 1993 remaining about $8 \mathrm{ft}$ to $11 \mathrm{ft}$ above the 1993 levels in the shallow and deep parts of the Equus Beds aquifer (table 3).

The storage-volume increased in the shallow part of the Equus Beds aquifer from 1993 to summer 2012 by about 20,000 acre-ft in the study area (table 3 ). As noted previously, storage volume was not computed separately for the deep part of the Equus Beds aquifer because of the complications caused by the semiconfined to confined conditions in the Equus Beds aquifer. The storage-volume increased in the CENWWF by about 46,300 acre-ft indicating that more than one-half of the increase in the CENWWF was offset by decreases in the rest of the study area. The decreases in storage volume outside the CENWWF probably were because of the increase in irrigation pumpage outside the CENWWF in 2011 and 2012 (fig. 15). This resulted from drought conditions and the availability of irrigation drought-term and MYFA permits that allowed irrigators to pump more than their annual authorized amounts in those years. The larger increase in storage-volume in the CENWWF than in the rest of the study area probably was because of Wichita's reduction in city pumpage from the Equus Beds aquifer that was adopted in 1993 as part of Wichita's ILWSP (City of Wichita, [2007?] and 2008; Warren and others, 1995; Desilva and Ary, 2011).

\section{Summary}

Development of the Wichita well field in the Equus Beds aquifer in southwest Harvey County and northwest Sedgwick County began in the 1940s to supply water to the city of Wichita. The decline of water levels in the Equus Beds aquifer was noted soon after the development of the Wichita well field began. Large-scale development of irrigation wells began in the 1960s. City and agricultural withdrawals have led to substantial water-level declines. Water-level declines likely enhanced movement of brines from past oil and gas activities near Burrton, Kansas, as well as natural saline water from the Arkansas River, into the well field area. Further movement into the well field area of these waters with large chloride concentrations may limit use or require treatment of water for irrigation or public supply. As water levels in the Equus Beds aquifer decline, the volume of water stored in the Equus Beds aquifer decreases and less water is available to supply future needs. In 1993, the city of Wichita adopted the Integrated Local Water Supply Program (ILWSP) to ensure an adequate water supply for the city through 2050 and as part of its effort to effectively manage the part of the Equus Beds aquifer it uses. The ILWSP uses several strategies to do this including the Equus Beds Aquifer Storage and Recovery (ASR) project. The purpose of the ASR project is to store water in the aquifer for later recovery, and to help protect the Equus Beds aquifer from the encroachment of a known oil-field-brine plume near Burrton, Kans., and saline water from the Arkansas River. Since 1940, the U.S. Geological Survey, in cooperation with the city of Wichita, has monitored changes in the Equus Beds aquifer as part of Wichita's effort to manage this resource effectively.

In winter 2012, summer 2012, winter 2013, and winter 2014, water-level altitudes in the shallow and deep parts of the Equus Beds aquifer indicated that flow continued to be generally from west to east in the study area with a large area of recharge in the northwest in the shallow part of the Equus Beds aquifer. In contrast, the water-level altitudes in summer 2012, when the most wells recorded low water levels for the winter 2012 to winter 2014 period, indicated flow was from 


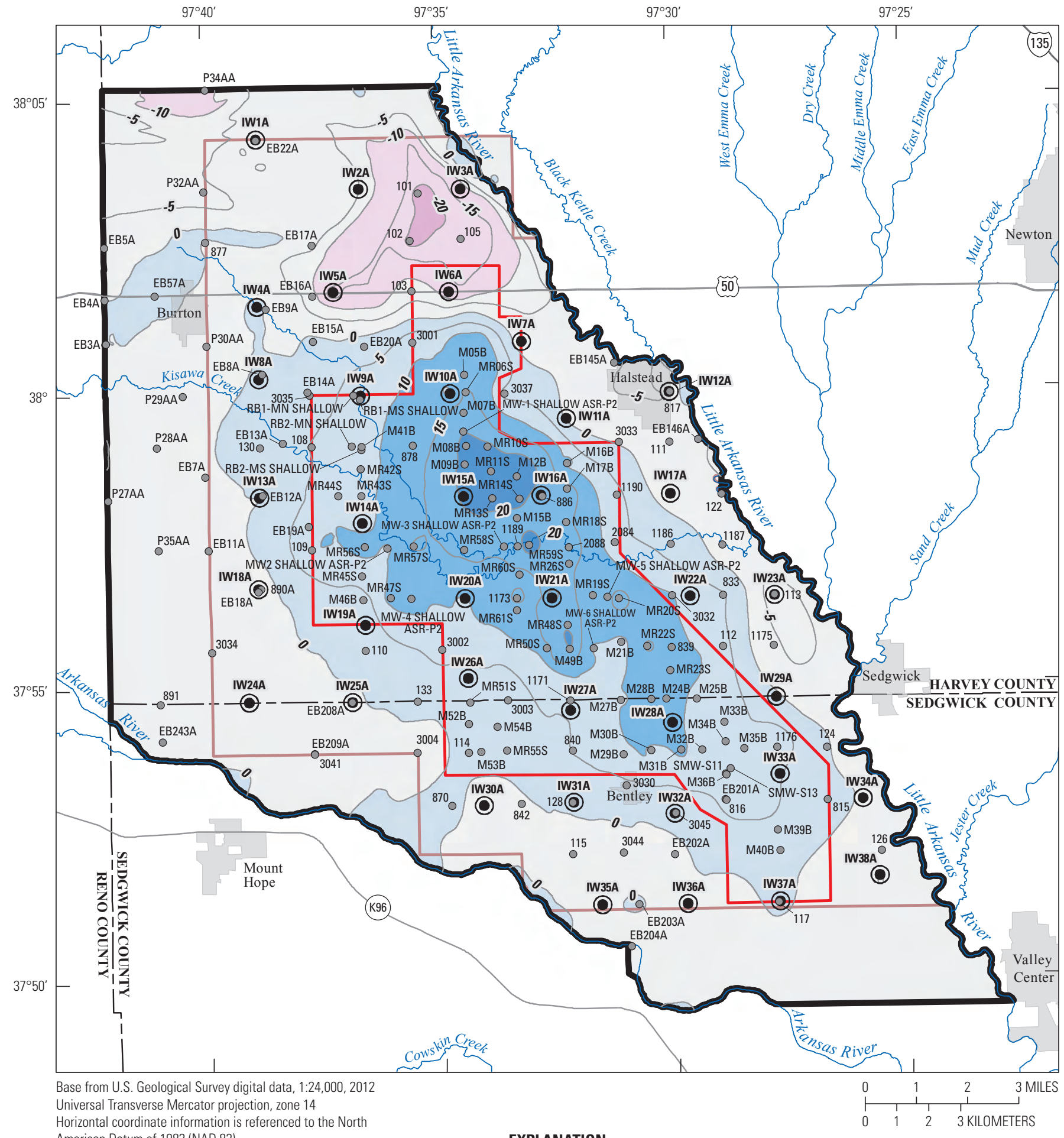

American Datum of 1983 (NAD 83)

\section{EXPLANATION}

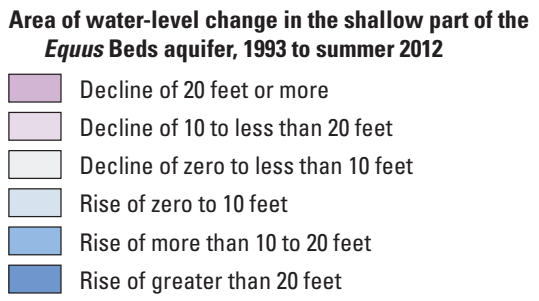

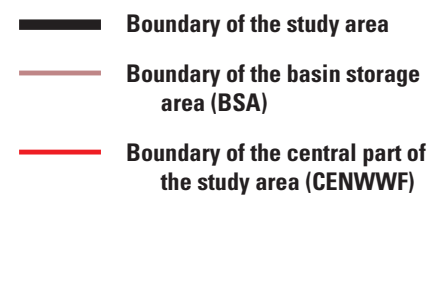

- 0 - Line of equal water-level change in the shallow part of the Equus Beds aquifer, 1993 to summer 2012Contour interval 5 feet
$\stackrel{1}{1636 A}$
Index monitoring well in the shallow part of the Equus Beds aquifer and identifier

EB204A

Figure 18. Water-level changes in the shallow part of the Equus Beds aquifer, 1993 to summer 2012. 


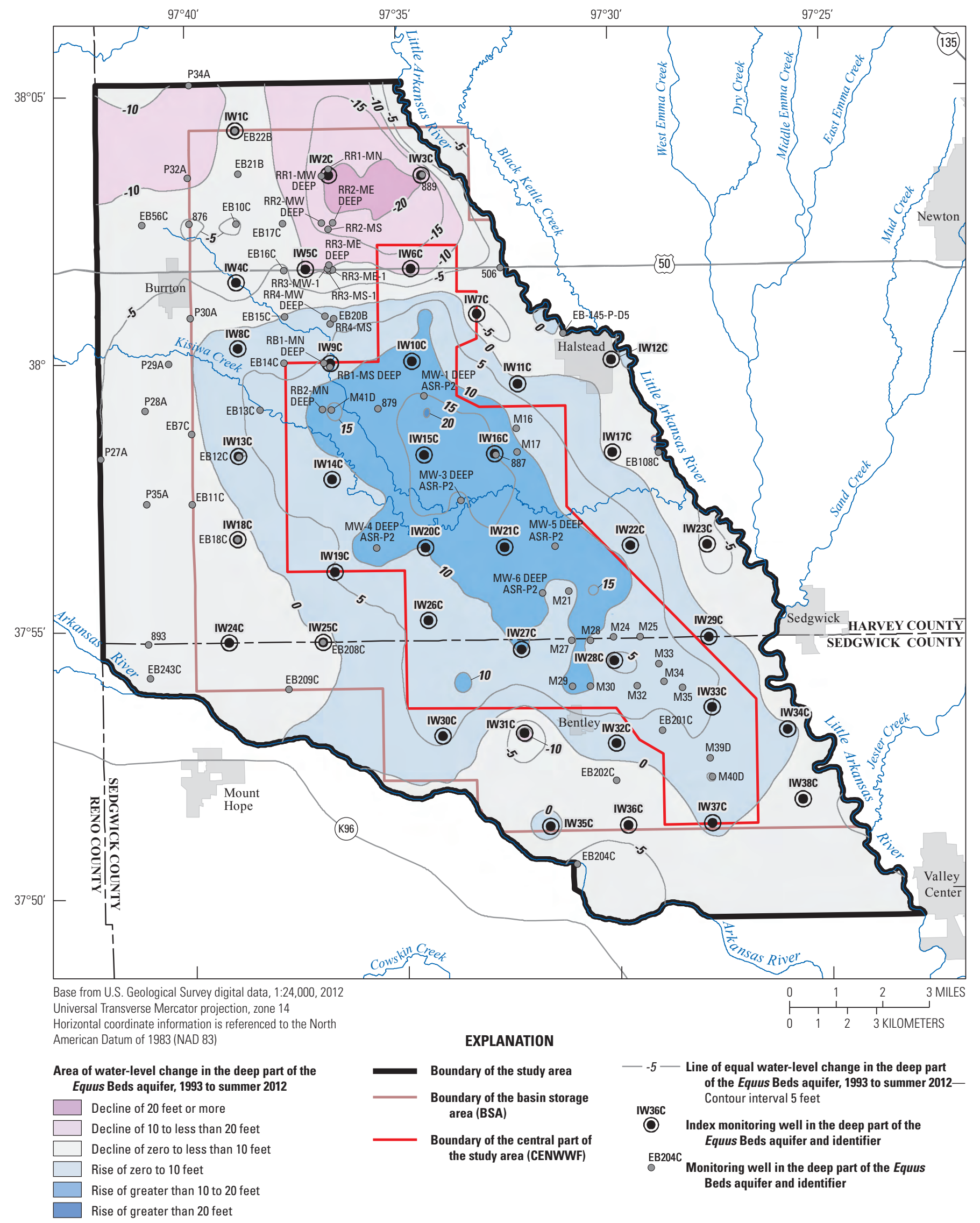

Figure 19. Water-level changes in the deep part of the Equus Beds aquifer 1993 to summer 2012. 
east to west in the area west and northwest of Halstead, Kans. as water that formerly discharged to the Little Arkansas River was pumped out of the Equus Beds aquifer by wells.

Average water-level changes since predevelopment for winter 2012, summer 2012, winter 2013, and winter 2014 generally indicated greater declines in the central part of the study area (CENWWF) than in either the basin storage area (BSA) or entire study area. However, average water-level rises since 1993 for winter 2012, summer 2012, winter 2013, and winter 2014 indicate the CENWWF had more post-1993 water-level recovery than did the rest of the study area. City water use in the CENWWF peaked in 1992, decreased by about 40 percent by 1997, and remained near that level through 2013. Irrigation water use in the CENWWF increased by only about 3 percent compared to its pre-1993 peak in 1991, whereas irrigation water use outside the CENWWF increased by about 24 percent from its pre-1993 peak in 1991. Part of the increase in irrigation pumpage probably was a result of the droughtterm and multiyear flex account permits, which were estimated to account for about 8 and 4 percent of irrigation pumpage in the study area in 2011 and 2012.

There was a larger percentage storage-volume increase since 1993 for winter 2012, summer 2012, winter 2013, and winter 2014 in the CENWWF than in either the BSA or the entire study area. Storage volume in the CENWWF during 2012 to 2014 recovered by about 46,300 acre-feet (acre-ft) or more compared to the storage volume in 1993. In summer 2012 and winter 2013, the storage-volume increase since 1993 was larger in the CENWWF than in the entire study area indicating that storage-volume increases in the CENWWF were offset by storage-volume decreases in the rest of the study area. The larger storage-volume increase in the CENWWF than in the rest of the study area probably was because of Wichita's ILWSP strategy that reduced city pumpage from the Equus Beds aquifer by about 40 percent. The current (winter 2014) storage-volumes in the entire study area and the central part of the study area are about 94 and 96 percent of their predevelopment storage volumes, or about $3,067,00$ and 962,000 acre-ft.

\section{References Cited}

Aucott, W.R., and Myers, N.C., 1998, Changes in groundwater levels and storage in the Wichita well field area, south-central Kansas, 1940-98: U.S. Geological Survey Water-Resources Investigations Report 98-4141, 20 p.

Aucott, W.R., Myers, N.C., and Dague, B.J., 1998, Status of ground-water levels and storage in the Wichita well field area, south-central Kansas, 1997: U.S. Geological Survey Water-Resources Investigations Report 98-4095, 15 p.
Bayne, C.K., 1956, Geology and ground-water resources of Reno County, Kansas: Kansas Geological Survey Bulletin 120, 130 p. [Also available at http://www.kgs.ku.edu/ General/Geology/Reno/index.html.]

City of Wichita, [2007?], Wichita area future water supplyA model program for other municipalities: Wichita, Kans., accessed July 9, 2013, at http://www.wichita.gov/ Government/Departments/PWU/UtilitiesDocuments/ WICHITA\%20AREA\%20FUTURE\%20WATER\%20 SUPPLY.pdf.

City of Wichita, 2008, City of Wichita, KS meeting the demands of a growing community: Transformations, Alliance for Innovation newsletter, v. 2, no. 3, p. 6.

Cunningham, W.L., and Schalk, C.W., comps., 2011, Groundwater technical procedures of the U.S. Geological Survey: U.S. Geological Survey Techniques and Methods, book 1, sec. A1, $151 \mathrm{p}$.

Desilva, Viraj, and Ary, Deb, 2011, Aquifer storage and recovery program remedies Wichita's groundwater problems: Journal of the American Water Works Association, v. 103, no. 6 , p. 94-99.

Esri, 2012a, ArcGIS help 10.1-Contour (Spatial Analyst) : Esri, accessed August 26, 2014 at http://resources.arcgis. com/en/help/main/10.1/index.html\#//009z000000ts000000.

Esri, 2012b, ArcGIS help 10.1-How topo to raster works: Esri, accessed August 26, 2014 at http://resources.arcgis. com/en/help/main/10.1/index.html\#/How_Topo_to_Raster works/009z0000007m000000/.

Gibson, Campbell, 1998, Population of the 100 largest cities and other urban places in the United States-1790-1990: U.S. Census Bureau, Population Division Working Paper no. 27 accessed January 10, 2010, at http://www.census.gov/ population/www/documentation/twps0027/twps0027.html.

Hansen, C.V., 2007, Status of ground-water levels and storage volume in the Equus Beds aquifer near Wichita, Kansas, January 2003-January 2006: U.S. Geological Survey Scientific Investigations Report 2006-5321, 34 p. [Also available at $h t t p: / / p u b s . u s g s . g o v / s i r / 2006 / 5321 /$.

Hansen, C.V., 2009a, Status of ground-water levels and storage volume in the Equus Beds aquifer near Wichita, Kansas, July 2008: U.S. Geological Survey Scientific Investigations Map 3075, scale 1:84,480. [Also available at: http://pubs. usgs.gov/sim $/ 3075 /$.

Hansen, C.V., 2009b, Status of groundwater levels and storage volume in the Equus Beds aquifer near Wichita, Kansas, January 2009: U.S. Geological Survey Scientific Investigations Map 3087, scale 1:84,480. [Also available at $h t t p: / /$ pubs.usgs.gov/sim/3087/.] 
Hansen, C.V., 2011a, Status of groundwater levels and storage volume in the Equus Beds aquifer near Wichita, Kansas, July 2010: U.S. Geological Survey Scientific Investigations Map 3159, scale 1:84,480. [Also available at http://pubs. usgs.gov/sim/3159/.]

Hansen, C.V., 2011b, Status of groundwater levels and storage volume in the Equus Beds aquifer near Wichita, Kansas, January 2011: U.S. Geological Survey Scientific Investigations Map 3192, scale 1:84,480. [Also available at http:// pubs.usgs.gov/sim/3192.]

Hansen, C.V., 2012, Status of groundwater levels and storage volume in the Equus Beds aquifer near Wichita, Kansas, July 2011: U.S. Geological Survey Scientific Investigations Map 3208, 1 sheet, scale 1: 84,480. [Also available at http:// pubs.usgs.gov/sim/3208.]

Hansen, C.V., and Aucott, W.R., 2001, Status of ground-water levels and storage volume in the Wichita well field area, south-central Kansas, 1998-2000: U.S. Geological Survey Water-Resources Investigations Report 00-4267, 27 p.

Hansen, C.V., and Aucott, W.R., 2004, Status of groundwater levels and storage volume in the Equus Beds aquifer near Wichita, Kansas, January 2000-January 2003: U.S. Geological Survey Water-Resources Investigations Report 03-4298, 36 p. [Also available at http://pubs.usgs.gov/wri/ wrir034298/.]

Hansen, C.V., and Aucott, W.R., 2010, Status of groundwater levels and storage volume in the Equus Beds aquifer near Wichita, Kansas, January 2006 to January 2010: U.S. Geological Survey Scientific Investigations Report 2010-5231, 42 p. [Also available at http://pubs.usgs.gov/ sir/2010/5231/.]

Hansen, C.V., Lanning-Rush, J.L., and Ziegler, A.C., 2013, Revised shallow and deep water-level and storage-volume changes in the Equus Beds aquifer near Wichita, Kansas, predevelopment to 1993: U.S. Geological Survey Scientific Investigations Report 2013-5170, 18 p. [Also available at http://pubs.usgs.gov/sir/2013/5170/.]

Heath, R.C., 1983, Basic ground-water hydrology: U.S. Geological Survey Water Supply Paper 2220, 84 p. [Also available at http://pubs.er.usgs.gov/publication/wsp2220.]

Helsel, D.R. and Hirsch, R.M., 2002, Statistical methods in water resources: U.S. Geological Survey Techniques of Water-Resources Investigations, book 4, chapter A3, 510 pages.

Juracek, K.E., and Hansen, C.V., 1995, Digital maps of the extent, base, top, and 1991 potentiometric surface of the High Plains aquifer in Kansas: U.S. Geological Survey Open-File Report 95-758, scales 1:500,000 and $1: 1,000,000$.
Kansas Department of Agriculture, 2005, In the matter of the city of Wichita's applications to operate an aquifer storage and recovery project in Harvey and Sedgwick Counties, Kansas-Applications to appropriate water, file nos. 45,567; 45,568; 45,569; 45,570; 45,571; 45,572; 45,573; 45,574; 45,575; 45,576; and 46,081: Topeka, Kans., Kansas Department of Agriculture, Division of Water Resources, August 8, 2005, 21 p.

Kansas Department of Agriculture, 2009, Approval of application and permit to proceed-Application for file no. 46,627: Topeka, Kans., Kansas Department of Agriculture, Division of Water Resources, September 18, 2009.

Kansas Department of Agriculture, 2011, Wichita well field sees improved water levels: DWR Currents, April 14, 2011 [n.p.], accessed February 13, 2012, at http://www.ksda. gov/dwr/content/314/cid/1773.

Kansas Department of Agriculture, Division of Water Resources, 2011, Procedural guideline-2011 Emergency drought term permit applications updated August 16, 2011: Topeka, Kans., Kansas Department of Agriculture, Division of Water Resources, chap. 6, pt. A, 3 p., accessed April 30, 2014, at http://agriculture.ks.gov/docs/default-sourcel statues-water/guidance-document-nbsp-drought-termpermits.pdf?sfursn $=0$.

Kansas Department of Agriculture and Kansas Geological Survey, 2014, Water Information Management and Analysis System (WIMAS) for the Web: Kansas Department of Agriculture, Division of Water Resources database, accessed January 22, 2014, at http://hercules.kgs.ku.edu/geohydro/ wimas/index.cfm.

Kansas Geological Survey, 1992, Geology: Kansas Data Access and Support Center, accessed August 13, 2014 at http://www.kansasgis.org/catalog/index.cfm?data_ $i d=255 \& S H=$ geology?data_id $=255 \&$ show_cat $=99$.

Kansas Geological Survey, 2014, WIZARD water-level database: Kansas Geological Survey database, accessed January 23, 2014, at http://www.kgs.ku.edu/Magellan/WaterLevels/ index.html.

Kansas Legislative Research Department, 2012, Multi-year flex accounts for water-SB 272 in 2012 Summary of Legislation: Topeka, Kans., Legislature, 2 p., accessed April 30, 2014, at http://www.kslegislature.org/li_2012/b2011_12/ measures/documents/summary_sb_272_2012.pdf.

Kelly, B.P., Pickett, L.L., Hansen, C.V., and Ziegler, A.C., 2013, Simulation of groundwater flow, effects of artificial recharge, and storage volume changes in the Equus Beds aquifer near the city of Wichita, Kansas well field, 19392008: U.S. Geological Survey Scientific Investigations Report 2013-5042, 90 p. [Also available at http://pubs. er.usgs.gov/publication/sir20135042.] 
Lane, C.W., and Miller, D.E., 1965, Geohydrology of Sedgwick County, Kansas: Kansas Geological Survey Bulletin 176, 100 p. [Also available at http://www.kgs.ku.edu/ General/Geology/Sedgwick/index.html.]

Leonard, R.B., and Kleinschmidt, M.K., 1976, Saline water in the Little Arkansas River Basin area, south-central Kansas: Kansas Geological Survey Chemical Quality Series 3, 24 p.

Lohman, S.W., 1972, Definitions of selected ground-water terms - Revisions and conceptual refinements: U.S. Geological Survey Water-Supply Paper 1988, 21 p. [Also available at http://pubs.usgs.gov/wsp/wsp_1988/.]

Myers, N.C., Hargadine, G.D., and Gillespie, J.B., 1996, Hydrologic and chemical interaction of the Arkansas River and the Equus Beds aquifer between Hutchinson and Wichita, south-central Kansas: U.S. Geological Survey WaterResources Investigations Report 95-4191, 100 p. [Also available at http://pubs.er.usgs.gov/publication/wri954191.]

National Oceanic and Atmospheric Administration, 2014a, Climate data online: Asheville, N.C., National Climatic Data Center, accessed April 14, 2014, at http://www.ncdc. noaa.gov/cdo-web/search.

National Oceanic and Atmospheric Administration, 2014b, Daily/monthly normals for Wichita Airport, KS: NOAA Online Weather Data, accessed April 16, 2014, at http:// www.nws.noaa.gov/climate/xmacis.php? wfo=ict.

Petri, L.R., Lane, C.W., and Furness, L.W., 1964, Water resources of the Wichita area, Kansas: U.S. Geological Survey Water-Supply Paper 1499-I, 69 p.

Pruitt, T., 1993, Arkansas River water management improvement study-Modeling of chloride transport in the Equus Beds aquifer: U.S. Department of the Interior, Bureau of Reclamation Technical Report, 96 p.

Sophocleous, M.A., 1983, Water quality modeling of the Equus beds aquifer in south-central Kansas: Kansas Geological Survey Open-File Report 83-1, 75 p.

Spinazola, J.M., Gillespie, J.B., and Hart, R.J., 1985, Groundwater flow and solute transport in the Equus beds area, south-central Kansas: U.S. Geological Survey WaterResources Investigations Report 85-4336, 68 p. [Also available at http://pubs.er.usgs.gov/publication/wri854336.]

Stramel, G.J., 1956, Progress report on the ground-water hydrology of the Equus beds area, Kansas: Kansas Geological Survey Bulletin 119, pt. 1, 59 p.

Stramel, G.J., 1962a, A review of the geology and hydrology of the Wichita well field: Wichita, Kans., City of Wichita Water Department, 29 p.
Stramel, G.J., 1962b, A preliminary review of artificial recharge potential in the area between Hutchinson and Wichita, Kansas: Wichita, Kans., City of Wichita Water Department, $21 \mathrm{p}$.

Stramel, G.J., 1967, Progress report on the ground-water hydrology of the Equus beds area, Kansas 1966: Kansas Geological Survey Bulletin 187, pt. 2, 27 p.

Stullken, L.E., Watts, K.R., and Lindgren, R.J., 1985, Geohydrology of the High Plains aquifer, western Kansas: U.S. Geological Survey Water-Resources Investigations Report 85-4198, 86 p. [Also available at http://pubs.er.usgs.gov/ publication/wri854198.]

U.S. Census Bureau, 2012, Intercensal estimates of the resident population for incorporated places and minor civil division-April 1, 2000 to July 1, 2010 (SUB-EST00INTTOT): U.S. Census Bureau, Population Division, accessed July 9, 2013, at http://www.census.gov/popest/data/ intercensal/cities/cities2010.html.

U.S. Geological Survey, 2012, Water-resources data for the United States, Water Year 2011: U.S. Geological Survey Water-Data Report WDR-US-2011, accessed August 22, 2014, at http://wdr.water.usgs.gov/.

U.S. Geological Survey, 2013, Water-resources data for the United States, Water Year 2012: U.S. Geological Survey Water-Data Report WDR-US-2012, accessed August 22, 2014 at http://wdr.water.usgs.gov/.

U.S. Geological Survey, 2014a, National Water Information System (NWISWeb): U.S. Geological Survey database, accessed February 5, 2014, at http://waterdata.usgs.gov/ks/ nwis/.

U.S. Geological Survey, 2014b, Water-resources data for the United States, Water Year 2013: U.S. Geological Survey, Water-Data Report WDR-US-2013, accessed August 22, 2014 at http://wdr.water.usgs.gov/.

Warren, D.R., Blain, G.T., Shorney, F.L., and Klein, L.J., 1995, IRP - A case study from Kansas: Journal of the American Water Works Association, v. 87, no. 6, p. 57-71.

Whittemore, D.O., 2007, Fate and identification of oil-brine contamination in different hydrogeologic settings: Applied Geochemistry, v. 22, no. 10, p. 2099-2114.

Whittemore, D.O., 2012, Distribution and change in salinity in the Equus Beds Aquifer in the Burrton Intensive Groundwater Use Control Area: Kansas Geological Survey Open-File Report 2012-1, 35 p.

Williams, C.C., and Lohman, S.W., 1949, Geology and ground-water resources of a part of south-central Kansas, with special reference to the Wichita municipal water supply: Kansas Geological Survey Bulletin 79, 455 p. 
Ziegler, A.C., Christensen, V.G., Ross, H.C., 1999, Baseline water-quality and preliminary effects of artificial recharge on ground water, south-central Kansas, 1995-98: U.S.

Geological Survey Water-Resources Investigations Report 99-4250, $74 \mathrm{p}$.

Ziegler, A.C., Hansen, C.V., and Finn, D.A., 2010, Water quality in the Equus Beds aquifer and the Little Arkansas River before implementation of large-scale artificial recharge, south-central Kansas, 1995-2005: U.S. Geological Survey Scientific Investigations Report 2010-5023, 143 p. [Also available at http://pubs.usgs.gov/sir/2010/5023/.] 


\section{Appendix}

Table 1-1. Measured and interpolated water-level altitudes in the Equus Beds aquifer, predevelopment, 1993, winter 2012, summer 2012, winter 2013, and winter 2014.

Located online at http://pubs.usgs.gov/sir/2014/5185/downloads/sir14-5185_table1-1.xlsx. 
Publishing support provided by: Rolla Publishing Service Center

For additional information concerning this publication, contact: Director, USGS Kansas Water Science Center 4821 Quail Crest Place

Lawrence, KS 66049

(785) 842-9909

Or visit the Kansas Water Science Center Web site at: http://ks.water.usgs.gov 
Back cover. No flow in the Little Arkansas River at Highway 50 near Halstead, Kansas, October 2, 2012. Photograph by Barbara J. Dague, U.S. Geological Survey. 

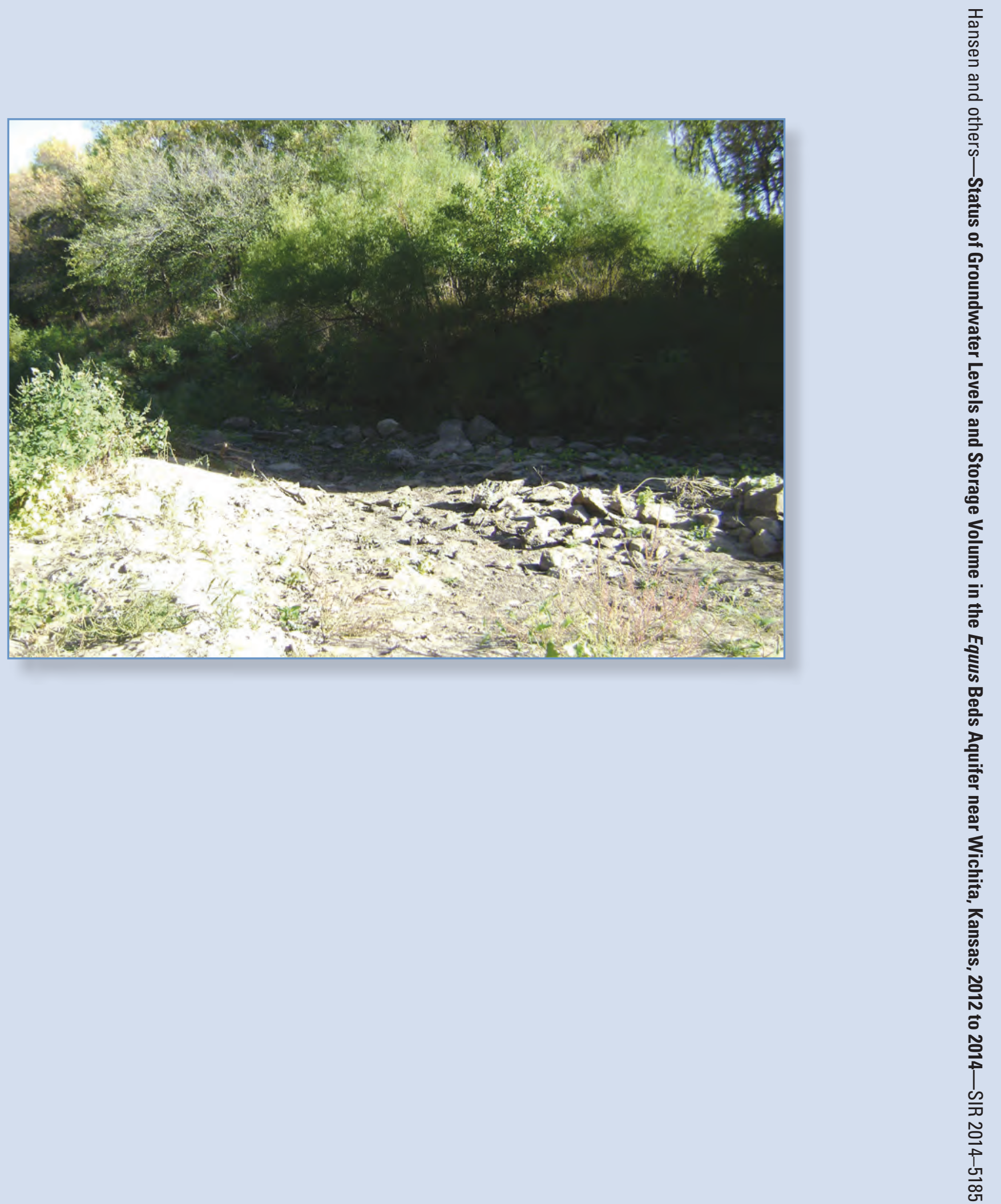